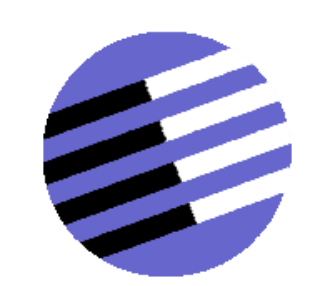

GOVERNANCE AND THE EFFICIENCY

OF ECONOMIC SYSTEMS

GESY

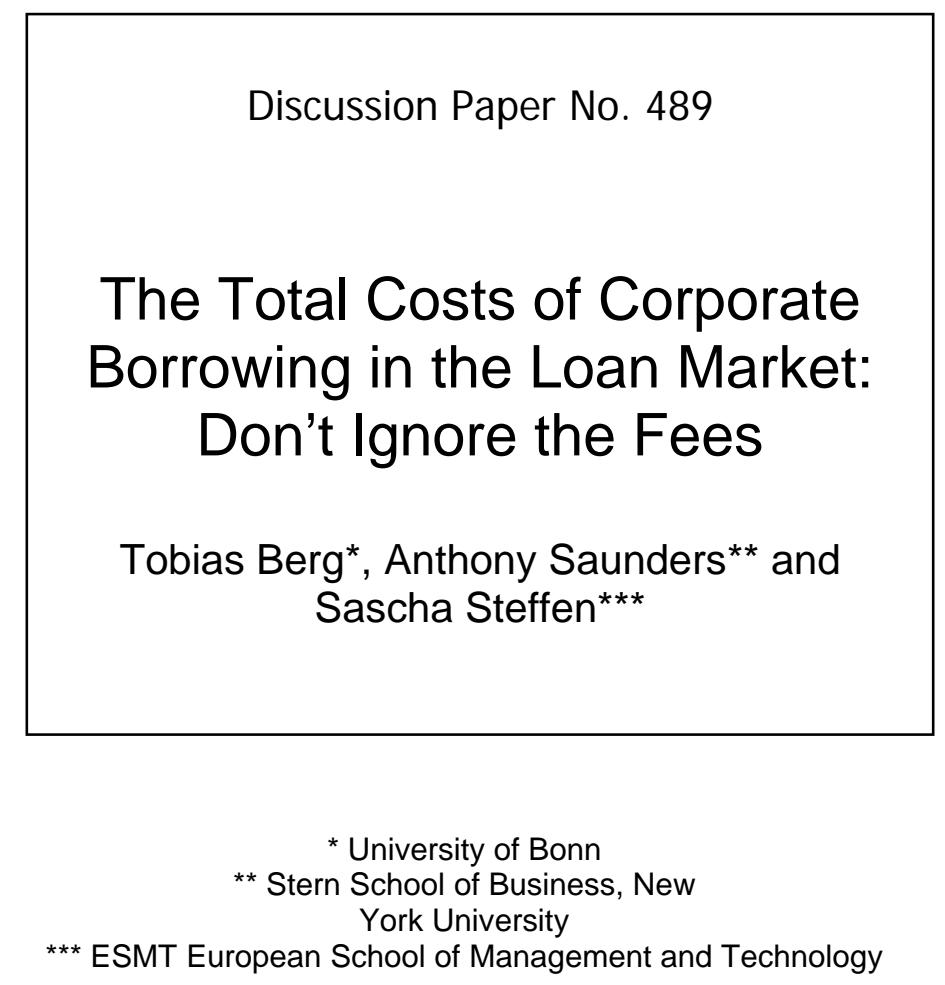

February 10, 2015

Financial support from the Deutsche Forschungsgemeinschaft through SFB/TR 15 is gratefully acknowledged.

Sonderforschungsbereich/Transregio $15 \cdot$ www.sfbtr15.de

Universität Mannheim · Freie Universität Berlin · Humboldt-Universität zu Berlin · Ludwig-Maximilians-Universität München Rheinische Friedrich-Wilhelms-Universität Bonn · Zentrum für Europäische Wirtschaftsforschung Mannheim 


\title{
The Total Costs of Corporate Borrowing in the Loan Market:
}

\author{
Don't Ignore the Fees
}

TOBIAS BERG, ANTHONY SAUNDERS, and SASCHA STEFFEN*

February 10, 2015

\begin{abstract}
More than $80 \%$ of US syndicated loans contain at least one fee type and contracts typically specify a menu of spread and different types of fees. We test the predictions of existing theories about the main purposes of fees and provide supporting evidence that: (1) fees are used to price options embedded in loan contracts such as the draw-down option for credit lines and the cancellation option in term loans; and (2) fees are used to screen borrowers about the likelihood of exercising these options. We also propose a new total-cost-of-borrowing measure that includes various fees charged by lenders.
\end{abstract}

* Tobias Berg is at the University of Bonn, Anthony Saunders is at the Stern School of Business, New York University, and Sascha Steffen is at the ESMT European School of Management and Technology. We thank Viral Acharya, Javed Ahmed, Bastian von Beschwitz, Lamont Black, Martin Brown, Michael Faulkender, Mark Flannery, Iftekhar Hasan, Elena Loutskina, Loretta Mester, Michael Roberts, Tao Shen, conference participants at the 2013 SFS Cavalcade in Miami, the 2013 FIRS meetings in Dubrovnik, the 2013 Bank Structure Conference in Chicago, the WFA 2013 meetings in Lake Tahoe, the EFA 2013 meetings in Cambridge, the DGF 2013 meetings, the CAREFIN 2013 conference at Bocconi, the 2014 Corporate Finance Workshop at Tsinghua University and seminar participants at Fordham University, the University of Bonn, and the University of St. Gallen for valuable comments and suggestions. In addition, we thank the editor, Michael Roberts, and three anonymous referees for their comments and suggestions. Tobias Berg gratefully acknowledges financial support from the Deutsche Forschungsgemeinschaft through SFB 649 "Economic Risk" and SFB-TR15 "Governance and the Efficiency of Economic Systems". 
Fees are an important part of corporate loan contracting. More than $80 \%$ of US syndicated loans contain at least one fee type and contracts typically specify a menu of spread and different types of fees. Despite this importance, the substantial empirical literature that studies private loan contracts largely ignores their complex pricing mechanisms and focuses on a single statistic such as an interest rate spread. ${ }^{1}$ Contracts, however, are not that simple as the following example suggests.

On June 16th, 2010, Meredith Corp., an American media conglomerate, entered into a USD 150mn credit line, a commitment by some banks under which Meredith can borrow up to the committed amount over a period of 36 months. The contract specifies that Meredith has to pay 50bps of the committed amount upfront. Moreover, during the 36 months, Meredith pays 37.5bps annually for each dollar that is committed but not borrowed. For each dollar borrowed under the commitment, it has to pay LIBOR plus 250bps (the interest rate spread). Obviously, it is insufficient to describe the contract by simply referring to the interest rate spread. On the contrary, fees are clearly important because of their magnitude and as they are intimately linked to states of the world in which Meredith decides to borrow or not to borrow under the commitment. $^{2}$

In this paper, we take a first step in analyzing the pricing structure and, in particular, the role of fees in corporate loan contracts. Why are fees in loan contracts and how are they differentially used in the most common loan types, credit lines and term loans? Why do fees come in various forms and combinations? And, how are fees set, that is, how do fees vary with borrower and other financial market characteristics?

\footnotetext{
1 A notable exception is the paper by Shockley and Thakor (1997). We extend their paper by empirically establishing the option-view of lines of credit and linking fees to the takedown behavior of borrowers.

2 The Dealscan FacilityID of this agreement is 256725. The full credit agreement is available via http://www.sec.gov/Archives/edgar/data/65011/000006501110000058/exh.htm. Information on spreads and fees can be found in Section 2.08 (spread) and Section 2.09 (fees).
} 
The theoretical literature on loan pricing provides clear predictions regarding the existence and magnitude of fees in corporate loan contracts. We start by revisiting these theories and identify two main purposes of fees: First, fees are used to price options embedded in corporate loan contracts (Thakor et al., 1981). Most credit lines and term loan contracts contain option-like features. The empirical loan pricing literature usually lumps credit lines and term loans together even though these contracts are inherently different. For example, the most widespread option is the option to draw down on a line of credit. Sufi (2009) reports that $82 \%$ of firm-years in the U.S. have a line of credit and even $32 \%$ of otherwise all equity financed firms have credit lines. At the time borrowers exercise this option, there is a value transfer from lenders to borrowers: borrowers choose to use the credit line if the committed interest rates is lower that the current spot market rate. Fees compensate lenders for granting this option. Similar arguments apply for the option to cancel a term loan - which is valuable for borrowers and thus requires compensation in the form of upfront or cancellation fees.

The second purpose of fees is to screen borrowers if they have private information about exercising any of the options embedded in a loan contract (Thakor and Udell, 1987), and to alter ex-post incentives. For example, a borrower can signal a low likelihood of future credit line usage by selecting into a contract with a high spread and a low commitment fee.

We provide empirical evidence consistent with these theories. First, we empirically verify the option-like characteristics of credit lines. In particular, we show that firms are more likely to draw on their lines of credit when their economic situation deteriorates. We group borrowers into quintiles based on realized equity returns in the first three years after loan origination and find significantly higher draw-downs from borrowers with the lowest returns. 
Second, consistent with this option-view of credit lines, we find that upfront fees and the All-in-spread-undrawn (AISU, commitment fee plus facility fee) are larger for high-volatility borrowers (measured as either equity volatility or volatility of borrower profitability). Furthermore, lines of credit with a spread-increasing performance pricing schedule have lower upfront fees and a lower AISU, consistent with the view that the draw-down option contained in credit lines is worth less if the loan spread increases as the borrowers' creditworthiness deteriorates.

Third, we provide evidence consistent with borrowers self-selecting into contracts based on their private knowledge about the likelihood of exercising the draw-down option. We find that borrowers who pay a lower AISU and a higher AISD (All-in-spread-drawn, spread plus facility fee) are less likely to draw on their line of credit consistent with Thakor and Udell (1987). For example, borrowers in the lowest AISU-to-AISD quintile have an average usage rate of $29 \%$ in the first three years after loan origination while borrowers in the highest AISU-toAISD quintile have average usage rates of $32 \%$. Furthermore, average usage rates are almost 10 percentage points lower for borrowers whose contracts specify a utilization fee - which apply once a borrower's usage exceeds a pre-specified commitment threshold (usually between $30 \%$ and $50 \%)$.

Our results further suggest that a low AISU-to-AISD ratio and the utilization fee are substitutes. In particular, we rarely observe utilization fees in the lowest AISU-to-AISD quintile (6\% of all contracts) but utilization fees are frequently used in the highest AISU-to-AISD quintile (24\% of all contracts). We test the screening hypothesis more formally using a positive correlation test (Finkelstein and Poterba, 2004; Finkelstein and McGarry, 2006) and the results support the univariate evidence. 
Our analysis of fees is a useful starting point in understanding the contracting environment surrounding corporate loan contracts. We document that lenders use a complex pricing structure to ensure an appropriate expected return rather than a single price measure, thereby accounting for the various options embedded in corporate loan contracts. However, once spreads and fees are set, we can use this pricing structure to estimate a cost measure that incorporates various fees charged by lenders. In the final part of the paper, we develop a comprehensive total-cost-of-borrowing measure (TCB) that accounts for fees, spread and the likelihood that they will have to be paid. We suggest that the TCB measure might be used as an alternative to the AISD in future research exploring the cost of debt.

There are a number of issues that have not been explored in this paper that require different types of analyses. We describe some of these issues throughout the paper. Overall, we need to better understand (both from a theoretical and empirical perspective) why certain options and fees exist and how they determine the timing and state in which value transfers between borrowers and lenders occur. Our paper is a first step in this direction.

The remainder of the paper is structured as follows. Section 1 provides basic stylized facts on the importance of fees in syndicated loan contracts. Section 2 derives hypotheses on the occurrence and magnitude of fees from prior theoretical work and provides empirical evidence alongside these hypotheses. Section 3 proposes a new and comprehensive total-cost-ofborrowing measure that includes the various fees being charged by the lenders. Section 4 concludes. 


\section{Data sources, loan types and options, fee types and definitions}

\section{A. Data sources}

We collect all syndicated loans issued by U.S. non-financial firms during the 1986 to 2011 period from the LPC Dealscan database. We obtain all spreads and fees as well as other relevant information including maturity, loan size, facility type, collateral and covenants and require that all key loan contract terms are available. ${ }^{3}$ Using the Dealscan-Compustat Linking Database (Chava and Roberts, 2008) we collect financial statement information from the merged CRSP/Compustat database for each borrower. We also collect data on credit line usage over the three years after origination from CapitalIQ, which has been available since 2000. Our final sample spans the 1986 to 2011 period and includes 32,343 loans from Dealscan to 5,481 publicly listed borrowers. 21,981 (68\%) of these loans are credit lines and 10,362 (32\%) are term loans (Table I).

[Table I]

We construct a second sample, hand-collecting fee information from a random sample of 1,000 syndicated loan facilities directly from electronic SEC filings and compare the fee information from these filings to Dealscan. If fee information is available in the SEC filings, Dealscan correctly reports these fees in more than $95 \%$ of the cases.

With respect to upfront fee, however, contracts filed with the SEC frequently refer to a non-public fee letter without disclosing the upfront fee directly. Dealscan provides more information related to upfront fees than is actually available in the SEC filings. The SEC filings specify an upfront fee in $10 \%$ of the cases, in a further $77 \%$ of the cases the contracts clearly indicate that an upfront fee exists but the magnitude is not available via public sources, in $20 \%$ of

\footnotetext{
${ }^{3}$ In particular, these contract terms include maturity, loan amount, AISD, and, for lines of credit, AISU.
} 
the cases there is no clear trace of an upfront fee in the SEC filings. ${ }^{4}$ Dealscan provides upfront fees in even $25 \%$ of the cases. That is, upfront fees are to some extent gathered from non-public sources (other than SEC filings) and Dealscan systematically produces more upfront fee information than the SEC filings. This suggests that, while borrower and loan characteristics of our samples with and without upfront fee information are broadly comparable, the omission of upfront fee information in Dealscan might not be idiosnycratic..$^{5}$ A detailed analysis and comparison of the SEC and Dealscan samples are available in our Online Appendix C.

\section{B. Loan types and options embedded in loan contracts}

The most important loan types are credit lines and term loans. ${ }^{6}$ The empirical loan pricing literature usually lumps both loan types together even though these contracts are inherently different. While credit lines are commitments of lenders to provide a loan at a contractually agreed spread in the future, term loans, in contrast, are fully funded at loan origination. Consequently, credit lines and term loans are also different with respect to options embedded in these loan contracts and - as will be discussed in the next subsection - in their pricing structure. We identify three main options included in loan contracts:

\footnotetext{
${ }^{4}$ As an example, the loan contract of Level 3 Communications dated as of Sep, $30^{\text {th }}$, 1999 specifies: "Level 3 and the Borrowers agree to pay to the Administrative Agent, for its own account, fees payable in the amounts and at the times separately agreed upon with the Administrative Agent." Indeed, for this specific loan contract, Dealscan reports an upfront fee of $87.5 \mathrm{bps}$, suggesting that Dealscan has obtained private information from the participating banks or the borrower.

${ }^{5}$ As an example, while our sample firms are publicly listed, private firms are usually not required to file with the SEC and Dealscan collects contract term information from private loan desks.

${ }^{6}$ Dealscan reports a variety of other loan types, such as letters of credit, leases or guarantees. These other loan types make up only $4 \%$ of the Dealscan observations and we thus exclude them our analysis
} 
Option to draw on a line of credit: Each line of credit provides the borrower with an option to draw at a pre-specified spread. Borrowers should be more likely to draw down their lines of credit when spot market spreads are high, that is, when the option is "in-the-money".

Option to terminate a loan contract: Most corporate loan contracts allow the borrower to terminate the loan contract before maturity. The option to terminate is particularly relevant for term loans. ${ }^{7}$ Firms should be more likely to terminate a term loan contract when spot market spreads are low. Terminations or renegotiations of loan contracts before the loan matures are widespread. For example, Roberts and Sufi (2009) report an unconditional likelihood of renegotiation of $9.1 \%$ per quarter, of which $4.2 \%$ are early terminations.

Option to request a competitive bid ("Competitive bid option $(C B O) ")$ : Some corporate loan contracts provide the borrower with the option to request a "competitive bid". A CBO allows the borrower to solicit the best bid from its syndicated group for a given borrowing (Taylor and Sansone (2007)). Therefore, the loan shares by the syndicate participants are backup shares in case no sufficient bids are obtained in any of these auctions. ${ }^{8}$

\section{Fee types and definitions}

Fess are an important component of syndicated loan contracts. As noted earlier, about $80 \%$ of the syndicated loans issued over the 1986-2012 period contain at least one fee type in the

\footnotetext{
${ }^{7}$ For credit lines, borrowers do not have to terminate the loan contract to avoid having to pay the full spread. Instead, borrowers can simply choose not to draw down the credit line.

${ }^{8}$ If, for example, two lenders each have a USD 50mn share of a USD 100mn revolver, each lender is still allowed to bid for a higher amount when the borrower requests liquidity from a credit line. In an extreme case, lender A might provide the whole USD 100mn loan if lender A bids for the total amount and lender B bids nothing.
} 
Dealscan database. ${ }^{9}$ We identify 5 different fee types that occur in more than $5 \%$ of all loan contracts. ${ }^{10}$

\section{[Figure 1]}

In particular, approximately $50 \%$ of the loans contain a commitment fee, almost $25 \%$ a facility fee and some syndicated loans even specify a "collateral monitoring fee". The average fee ranges from 12 bps (utilization fee) to 160 bps (cancellation fee) and is large compared to the average interest spread of 190 bps.

The fee structure of credit lines is more complex compared to term loans. For example, four main fee types are present in more than $10 \%$ of credit line contracts (upfront fee, facility fee, commitment fee, utilization fee) while only two fee types are used in more than $10 \%$ of term loan contracts (upfront fee, cancellation fee). As term loans are fully funded at origination, only a very small number of term loans specify a commitment fee.

In the following we briefly describe the major fee and spread components. We focus on those fees that are present in at least $10 \%$ of credit lines or term loans in our sample. ${ }^{11}$

(a) Spread over LIBOR: The spread over LIBOR is the interest margin above the interbank loan rate charged to borrowers on the drawn portion of the loan.

(b) Upfront Fee: The one-time fee paid by the borrower to lender(s) at the loan closing date. $^{12}$

\footnotetext{
${ }^{9}$ Online Appendix C contains detailed instructions how to extract the fee information from Dealscan.

${ }^{10}$ Dealscan also reports letter of credit fees. Letter of credits are separate products that are jointly offered with lines of credit, with the letter of credit fee being conceptually similar to a loan spread.

${ }^{11}$ The following definitions mainly follow Taylor and Sansone (2007).

${ }^{12}$ For term loans, the upfront fee is conceptually the same as the original-issue-discount (OID), that is, the borrower receives the notional reduced by the upfront fee/OID. Credit lines do not have an OID as they are not fully funded at origination.
} 
(c) Commitment Fee: The fee is paid by borrowers on unused loan commitments. Commitment fees are most frequently used in credit lines. For term loans, such fees are only used where the exact date of drawing down is not predetermined.

(d) Facility Fee: ${ }^{13}$ A facility fee is the annual fee paid on the entire committed amount, regardless of usage. Commitment fees and facility fees are usually mutually exclusive. In particular, credit lines contain one of these types of fees, but not both.

(e) Utilization fee: A utilization fee is payable if utilization exceeds a certain percentage, for example $30 \%$ or $50 \%$, of a credit line. On each day that this percentage is exceeded, the fee is payable on all utilizations of the credit line and not merely the portion that exceeds the utilization threshold.

(f) Cancellation fee: A cancellation fee is payable if the borrower cancels the credit agreement before maturity. It is usually found in institutional term loan tranches and decreases from the origination date to the maturity date (e.g. $3 \%$ in the first year, $2 \%$ in the second year, $1 \%$ thereafter).

Table II reports the occurrence of the major fee types segregated by credit ratings for credit lines and term loans.

[Table II]

Commitment fees and facility fees are generally substitutes and usually mutually exclusive of each other. $68.0 \%$ of the facilities on average include a facility fee (but not a commitment fee) while $28.9 \%$ include a commitment fee (but not a facility fee), with $3.0 \%$ of the facilities containing both fee types. The facility fee is used more frequently by investment grade

\footnotetext{
${ }^{13}$ The facility fee is labeled "annual fee" in Dealscan. We use the wording "facility fee" as this is usually used in the credit agreements.
} 
borrowers $(76.3 \%)$ while the commitment fee is used more frequently for non-investment grade borrowers $(88.7 \%)$. Interestingly, the usage of facility fees drops from $54.2 \%$ to $28.0 \%$ for $\mathrm{BB}+$ versus BBB- rated borrowers, that is, at the investment grade / non-investment grade boundary.

Utilization fees are more likely to be included in loans to borrowers of medium credit quality. Credit lines of $\mathrm{BBB}+$ rated borrowers contain a utilization fee in almost one out of two contracts. On the other hand, less than $3 \%$ of the loans to borrowers rated worse than BB contain a utilization fee.

Cancellation fees are more common in term loans of low quality borrowers. Only 5\% of loans extended to investment-grade rated borrowers include a cancellation fee. At the same time, however, the cancellation fee is included in $10 \%$ (23\%) of the loans extended to BB (B) rated borrowers, mainly in institutional tranches.

Overall, lenders do not use a single measure such as an interest rate spread to ensure an appropriate expected return. On the contrary, lenders use combinations of fees and spread and our stylized facts suggest that fees are not just idiosyncratic, but follow clear patterns as to the occurrence of certain fee types, for example as a function of borrower risk. Consequently, any calculation of an expected return on a loan has to take the fee structure into account, which varies with loan type and comprises some fees that are paid upfront and others that are a function of borrower behavior (such as drawdowns or cancellations). Importantly, this is very different than an expected return calculated based on an interest rate spread.

The following section discusses theories and provides empirical evidence of why fees are in loan contracts, why they come in various forms, and how fees might vary with different determinants. 


\section{Economic framework, hypotheses, and empirical evidence}

In this section, we provide an economic framework for the role of fees in the pricing structure of corporate loans, derive hypotheses from the economic framework, and provide empirical evidence. We mainly focus on credit lines (i.e., the majority of the sample) but also discuss some applications for term loans at the end of the section. Our main claim can be summarized as follows: Corporate loans contain various options for borrowers and lenders and the pricing (fee) structure reflects the uncertainty associated with these options. Importantly, fees are a compensation for options in loan contracts; fees are used to screen borrowers as to their likelihood of exercising certain options, and fees are used to alter ex-post incentives to exercise these options.

We use a common format to investigate the use of fees in loan contracts: First, we describe the economic rationale and theory underlying the use of fees in loan contracts. Second, we summarize this in a testable hypothesis. Third, we discuss the related empirical evidence. Section II.A. examines the role of fees as a compensation for options embedded in credit lines, Section II.B. provides evidence that fees are used for ex-ante screening. Section II.C. provides a brief discussion of ideas for further research.

\section{A. Fees as compensation for options embedded in corporate loan contracts}

\section{A.1. Option-view of lines of credit-Draw-down behavior}

Description: The theoretical literature views loan commitments as insurance against the deterioration of a firm's creditworthiness as it provides the option for the borrower to draw down the credit line (Thakor et al., 1981; Thakor, 1982; Ho and Saunders, 1983; Boot et al., 1987; Thakor and Udell, 1987; and Chateau, 1990, Shockley and Thakor, 1997). A borrower will only 
exercise this option when it is more costly to borrow in the spot market at current market rates. ${ }^{14}$ We thus directly get the following hypothesis as to the borrowers' draw-down behavior:

Hypothesis 1: Borrowers are more likely to draw down a line of credit if thei creditworthiness has deteriorated since origination than if their creditworthiness has improved.

Empirical evidence: While we cannot directly observe spot market spreads in the loan market, we can observe how the borrower's stock price and profitability have evolved after loan origination. Table III provides statistics on the usage of lines of credit based the development of the stock return (Panel A) and the change in profitability (EBITDA/sales) over the first three years after loan origination (Panel B). We thereby split the sample into sub-samples of investment-grade firms (IG), non-investment-grade firms (non-IG) and unrated firms. For each of these sub-samples, we sort the observations into quintiles based on stock returns (Panel A) and profitability (Panel B). Mean usage rates are lowest for investment grade borrowers, followed by non-investment grade and unrated borrowers. Within each sub-sample, we document that credit lines are more likely to be used if the borrower's economic performance deteriorates - in particular for non-investment grade and non-rated firms. ${ }^{15}$

We do not report mean difference tests for brevity, but the average drawdowns between the rating categories (IG vs. non-IG, IG vs. unrated and non-IG vs. unrated) are statistically

\footnotetext{
${ }^{14}$ This option-view of lines of credit is, of course, a simplified description of loan contracting. First, borrowers might exercise the option for other reasons - for example if they are credit rationed in the spot market (Thakor, 2005). Second, syndicated loans include provisions that either restrict credit line usage if the credit line is deep-inthe-money (via covenants or using the MAC clause, see Section II.C for a discussion) or make the draw-down more expensive for the borrower (via performance pricing, see Hypothesis 3 for a discussion).

${ }^{15}$ For profitability, we observe a slightly U-shaped pattern, with borrowers with a large decline (5th quintile) and a large increase in profitability (1st quintile) having higer usage rates than borrowers with a medium change in profitability. However, the difference between mean usage rates of borrowers in the 1st and 3rd quintile is only significant at the $10 \%$ level, while the difference between the $3 \mathrm{rd}$ and the 5th quintile is highly statistically significant at the $1 \%$ level.
} 
significant. This is consistent with what we would expect. Unrated firms are more bankdependent and have access to fewer outside funding options. We expect unrated firms to use credit lines more extensively, ceteris paribus, compared to rated firms. A similar argument applies to the difference in drawdowns of lower versus higher rated firms. Lower (i.e., non-IG) rated firms might have more problems raising external capital relative to better rated firms suggesting higher usage rates. In multivariate regressions, we also find that investment grade borrowers are more likely to use a facility fee while non-investment grade borrowers are more likely to use a commitment fee. ${ }^{16}$

Appendix Table 1 extends the analysis to a multivariate setting. In particular, we control for rating fixed effects on the rating notch level, loan characteristics (logarithm of the facility amount, logarithm of the maturity, secured-dummy, sole-lender-dummy, syndicate size, and lead size), borrower characteristics (logarithm of total assets, logarithm of coverage ratio, leverage, profitability, asset tangibility, current ratio, and the market-to-book ratio), and year, loan purpose, loan type and one-digit SIC code fixed effects.. These control variables are described in more detail in Appendix A and are used throughout this paper in all multivariate settings. The multivariate analysis confirms the univariate results. Thus, consistent with the option-view, lines of credit are more likely to be used if a borrower's fundamental credit quality deteriorates.

[Table III]

\footnotetext{
${ }^{16}$ There is also anecdotal evidence that IG rated firms, that is, those firms with access to short-term commercial paper markets, usually use credit lines not as alternative funding source but rather as "backup" for commercial paper programs. Commercial paper is short-term (1-270 days) and usually uncollateralized, thus short-term investors are more willing to provide funding as they can be repaid by firms drawing down their credit lines if necessary. In other words, the option to draw facilitates funding in commercial paper markets.
} 


\section{A.2. Option-view of lines of credit-Pricing of the draw-down option}

Description: The option-view of lines of credit implies that, when a borrower draws from the credit line, there is a wealth transfer from lenders to borrowers. In other words, borrowing under loan commitments is a negative NPV loan for banks and they will demand compensation ex-ante for the expected loss under the commitment. Upfront fees and unused fees (AISU) are part of the pricing structure to compensate banks for writing this option. ${ }^{17}$ Ceteris paribus, an option is more likely to be in the money if the volatility of the underlying (i.e., the volatility of the borrower's creditworthiness) is high (Black and Scholes (1973)). Thus, upfront fees and unused fees should be an increasing function of the borrower's creditworthiness volatility:

Hypothesis 2: Upfront fees and the All-in-spread-undrawn (commitment and facility fees) are increasing functions of the borrowers' creditworthiness volatility.

Empirical evidence: We use the realized volatility of the borrower's equity return over the year prior to the loan origination date as a proxy for the volatility of the borrower's loan spot market spread. For each of the subsamples of investment-grade, non-investment grade and unrated borrowers, we group the facilities into quintiles based on the firm's equity volatility and report the results in Table IV. We analyze both upfront fees (Panel A) and the AISU (Panel B) across these quintiles and split the sample into sub-samples of investment-grade (IG), noninvestment-grade (non-IG) and unrated firms.

\section{[Table IV]}

\footnotetext{
${ }^{17}$ We do not discuss the rationale for paying for the draw-down option via upfront or unused fees here. Please note that outside the loan market, option prices are sometimes paid via upfront payments (e.g. call options on stocks) while others are paid with a mix of upfront payments and annual payments (e.g. credit default swaps). We discuss possible reasons for the choice of upfront versus unused fees in section II.C.
} 
For example, upfront fees increase from 25bps (lowest volatility) to 44bps (highest volatility) for investment-grade borrowers and the differences across volatility quintiles are large and statistically significant. This pattern extends to non-IG and unrated firms. Interestingly, we observe the steepest increase in upfront fees for non-IG borrowers. We observe a similar pattern for the AISU, that is, firms with higher equity volatility have a significantly larger AISU.

We perform various robustness tests that we report in Appendix Table 2. First, we report multivariate results controlling for loan and borrower characteristics as well as as well as rating notch, year, loan purpose, loan type and one-digit SIC code fixed effects. (Panel I). Second, we use the volatility of the borrower's profitability (EBITDA/Sales) in the five years prior to origination as an alternative proxy for the volatility of the unobservable loan spot market spread of the borrower (see Panel II). Third, we look at pairs of term loans and lines of credit that fulfill the following criteria: i) the term loan and the line of credit are originated by the same firm on the same day ii) the AISD specified in the line of credit is similar $(+/-15 \%)$ to the spread specified in the term loan contract (see column (3) and (6) in all Panels of Appendix Table 2). Basically, this procedure only looks at at-the-money options and thus ensures that strike prices are aligned with the firm's current creditworthiness. In all three robustness tests, the upfront fee and AISU are an increasing function of the firm's creditworthiness volatility. ${ }^{18}$

Taken together, our results suggest that a higher volatility of stock returns and profitability measures are associated with higher upfront fees and a higher AISU, consistent with

\footnotetext{
${ }^{18}$ Our model specifications also control for the syndicate structure such as the number of lenders as well as number of lead arrangers, as supply effects could influence the pricing and fee structure. While the number of lenders does not enter significantly into the regression, we find that a larger number of lead arrangers increases upfront fees significantly. In other tests, we include lender fixed effects to control for the possibility that there are (timeinvariant) differences between lenders in charging fees. Overall, these tests do not change the results presented in this paper. Results using lender fixed effects are reported in Online Appendix A.
} 
the hypothesis that lenders demand higher compensation if borrowers are more likely to draw down their credit lines.

\section{A.3. Option-view of lines of credit - The role of performance pricing}

Description: A large percentage of loans includes performance-pricing provisions (Asquith et al. (2005), Manso et al. (2010), Begley (2013), Adam et al. (2014)). These loans include performance pricing (PP) grids that are state contingent mappings from a borrower's economic condition (measured via ratings or financial ratios) to loan spreads. This feature has important implications for the options embedded in credit lines and therefore for fees: The option to draw down a credit line becomes less valuable if the spread increases as the borrower's economic condition deteriorates ("spread-increasing performance pricing"). On the contrary, the option is more valuable if the spread decreases if the borrower's economic condition improves ("spread-decreasing performance pricing"). ${ }^{19}$ If the AISD of a credit line fully adjusts to the level of the current market interest rate (and thus reflects the riskiness of the borrower), then the option value is zero and we would not expect to see any compensation in terms of fees. ${ }^{20} \mathrm{We}$ summarize this in the following hypothesis:

Hypothesis 3: Upfront fees and the All-in-spread-undrawn (commitment and facility fees) are lower for lines of credit that include a spread-increasing performance pricing provision and higher for lines of credit with a spread-decreasing performance pricing schedule.

\footnotetext{
${ }^{19}$ This only holds if the spread can decrease to levels below the spot market spread. If, for example, the credit line spread decreases from $100 \mathrm{bps}$ to $50 \mathrm{bps}$ after a downgrade and the spot market spread only decreases from $100 \mathrm{bps}$ to $70 \mathrm{bps}$, then this decreasing performance pricing scheme increases the option value for the borrower.

${ }^{20}$ Consistent with this hypothesis, Ivanov et al. (2014) find that market-based pricing - that is, tying loan interest rate spreads to credit default swap spreads - significantly reduces fees for lines of credit. While Ivanov et al. (2014) attribute the lower fees to a reduction in monitoring costs, their findings can also be explained with a simple optionview of lines of credit.
} 
Empirical evidence: We document that $52 \%$ of all credit lines contain a PP schedule. PP can adjust the spread in both ways: It can increase the spread if the economic condition deteriorates (increasing PP) or increase the spread if the economic condition improves (decreasing PP). For each credit line, we determine the current spread at origination $\left(\operatorname{Spread}_{\text {current }}\right)$, as well as the maximum spread $\left(\operatorname{Spread}_{\max }\right)$ and the minimum spread $\left(\operatorname{Spread}_{\min }\right)$ based on the PP grid and group credit lines into three categories: If $\operatorname{Spread}_{\min }=\operatorname{Spread}_{\max }$, we assign the line of credit to the category "No performance pricing" (10,555 of 21,981 observations $=48 \%$ ). If $\operatorname{Spread}_{\max }-\operatorname{Spread}_{\text {current }} \geq \operatorname{Spread}_{\text {current }}-\operatorname{Spread}_{\min }$, that is, the spread can increase more than it can decrease, the credit line is "PP-predominantly increasing" (6,038 of 21,981 observations $=27 \%$ ). Finally, if $\operatorname{Spread}_{\max }-\operatorname{Spread}_{\text {current }}<\operatorname{Spread}_{\text {current }}-\operatorname{Spread}_{\min }$, that is, the spread can decrease more than it can increase, we assign the line of credit to the category "PPpredominantly decreasing" $(5,388$ of 21,981 observations $=25 \%){ }^{21}$

We analyze upfront fees and AISU across the volatility quintiles for all three cases (no performance pricing, PP - predominantly increasing, PP - predominantly decreasing). The results are reported in Table $\mathrm{V}$. We find that, on average, mean upfront fees and AISU are significantly lower when credit lines contain an increasing PP schedule, consistent with the interpretation that PP lowers the option value to draw from the credit line. The differences are economically and statistically significant: Increasing PP schemes have 13-19 bps lower upfront fees and 4-6 bps lower unused fees (column (5) in Table V). Credit lines with decreasing PP schemes have higher unused fees - consistent with an increase in the option value - but upfront

\footnotetext{
${ }^{21}$ For 906 out of 21,981 observations, the performance pricing is "symmetric", that is, spreads can increase exactly as much as they can decrease $\left(\operatorname{Spread}_{\max }-\operatorname{Spread}_{\text {current }} \geq \operatorname{Spread}_{\text {current }}-\operatorname{Spread}_{\min }\right)$. Our results remain very similar if we would either drop these observations or assign these lines of credit to the class "PP - predominantly decreasing".
} 
fees are not significantly different compared to the "no performance pricing" case (column (4) in Table V).

\section{[Table V]}

Again, we perform various robustness tests that we report in Appendix Table 3. In particular, we report multivariate results controlling for loan and borrower characteristics as well as rating notch, year, loan purpose, loan type and one-digit SIC code fixed effects. We also develop a continuous performance pricing measure, defined as $\left(\operatorname{Spread}_{\max }-\operatorname{Spread}_{\text {current }}\right)-$ $\left(\operatorname{Spread}_{\text {current }}-\operatorname{Spread}_{\min }\right)$, where $\operatorname{Spread}_{\max }\left(\operatorname{Spread}_{\min }\right)$ is the maximum (minimum) spread under the PP schedule and Spread $_{\text {current }}$ is the spread the borrower has to pay for draw-downs based on his rating / financial characteristics at origination. This continuous measure is high and positive if the spread can increase (but not decrease) significantly under the PP schedule. It is low and negative if the PP schedule allows for a significant decrease (but not increase) of loan spreads. Thus, the results from the univariate analysis are confirmed in both cases. ${ }^{22}$

\section{A.4. Option-view of lines of credit - The competitive bid option (CBO)}

Description: As our descriptive evidence in Table II shows, facility fees and commitment fees are usually mutually exclusive. Moreover, high quality borrowers (those with an IG rating) are more likely to have a facility fee while low quality borrowers are more likely to have a commitment fee. There is no theoretical guidance as to why contracts should contain either of these two recurring fee types. Note that commitment fees are only paid on the undrawn portion of the credit line while facility fees are always paid on the entire committed amount. In principle,

\footnotetext{
${ }^{22}$ Utilization fees - that apply if usage exceeds a certain threshold - are conceptually similar to performance pricing schemes. Since utilization is negatively correlated with a borrower's economic performance (see Hypothesis 1), utilization fees are more likely to apply when a borrower has been downgraded and/or fundamentals have deteriorated. In unreported results, we show that contracts with utilization fees have lower upfront fees and lower unused fees (AISU), which is consistent with the results we obtain for performance pricing schemes.
} 
however, a contract with a spread and a commitment fee can generate the same state-contingent payments as a contract with a spread and a facility fee. ${ }^{23}$ This sub-section provides a first step in explaining this observed empirical regularity.

An important part of the explanation is the "Competitive Bid Option" (CBO). The CBO provides borrowers the option to solicit bids from syndicate lenders that specify the spreads based on which they are willing to lend a partial or even the full committed amount under the credit line. This can lead to a situation in which a line of credit is fully utilized, but some lenders do not provide any funds (because other lenders provide lower bids). Facilities with a CBO thus usually contain a facility fee to ensure that the lenders that do not lend under the CBO are still paid for their commitment. We thus expect to see a higher percentage of loans with CBO to have a facility fee and a higher percentage of loans without CBO to have a commitment fee.

Hypothesis 4: Lines of credit with a competitive bid option (CBO) are more likely to have a facility fee and less likely to have a commitment fee.

Empirical evidence: We test this hypothesis and report the results in Table VI.

[Table VI]

Panel A (Panel B) of Table VI shows the percentage of loans with a facility fee (commitment fee) for loans with and without CBOs and for sub-samples of IG, non-IG and unrated firms. As expected, loans with a CBO are significantly more likely to contain a facility fee and less likely

\footnotetext{
${ }^{23}$ A contract with a spread $\mathrm{X}$ and a facility fee $\mathrm{Y}$ generates the same state-contingent payments as a contract with a spread $\mathrm{X}+\mathrm{Y}$ and a commitment fee of $\mathrm{Y}$, namely $\mathrm{X}+\mathrm{Y}$ if the loan is drawn and $\mathrm{Y}$ if it is not drawn. With a competitive bid option, this is no longer true: A lender that does not provide funds for a fully drawn credit line still receives a facility fee, but does not receive anything if the contract specifies a commitment fee.
} 
to contain a commitment fee. The differences are economically and statistically highly significant. Our multivariate regressions tests (Appendix Table 4) confirm these results.

While the description and analysis of the $\mathrm{CBO}$ is a useful start in explaining the choice between facility fee and commitment fee, we do have to recognize some caveats: First, the CBO does not provide a full explanation of the choice of facility versus commitment fee: There are still contracts with $\mathrm{CBO}$ that do contain a commitment fee and there are non-CBO contracts that contain a facility fee. However, the existence of a $\mathrm{CBO}$ is by far the strongest predictor of the existence of a facility fee, with t-statistics of around 20 in a multivariate set-up (higher than all other explanatory variables).

Second, we do not try to explain why contracts include a CBO in the first place. The existence of a $\mathrm{CBO}$ is endogenous and it is beyond the scope of our paper to establish a causal link between the existence of a CBO and facility fees. A CBO with a facility fee seems like a redundant instrument: Why do borrowers want to include a CBO in a loan contract? It seems to us, that borrowers are always free to request additional bids in the spot market, regardless of whether they have a $\mathrm{CBO}$ or not. We think that the two points raised above might provide an interesting avenue for further research, but they are beyond the scope of our paper.

\section{B. Fees as a tool to facilitate ex-ante screening and control ex-post moral hazard}

\section{B.1. AISU versus AISD}

Description: If borrowers have private information about the likelihood of exercising options embedded in corporate loan contracts, fees can be used to encourage borrowers to selfselect into different contracts. Ergungor (2001) provides an excellent review of theories that rationalize the pricing structure of credit lines via asymmetric information or moral hazard 
arguments. In particular, Thakor and Udell (1987) and Shockley and Thakor (1997) provide a straightforward prediction that borrowers who expect a lower usage rate will self-select into contracts paying a low AISU and a high AISD. Thus, we have the following hypothesis:

Hypothesis 5: Borrowers who pay a lower AISU and a higher AISD are less likely to draw down their credit line.

Empirical evidence: Panel A of Table VII provides average usage ratios in the first 3 years after loan aggregation by AISU-to-AISD-ratio quintiles and rating status (investment grade, non-investment grade, not rated).

\section{[Table VII]}

Consistent with the screening hypothesis, we find that borrowers with low AISU/AISDratios have significantly lower ex-post utilization rates. The difference between the lowest and highest quintile by AISU/AISD-ratio ranges from $4.26 \%$ (investment grade) to $5.21 \%$ (not rated). These values are not only statistically significant, but also economically important given that the unconditional mean usage rates are approximately $20 \%$ (investment grade) and 30-35\% (non investment grade and not rated).

A more formal test of this adverse selection story is the positive correlation test (Finkelstein and Poterba, 2004; Finkelstein and McGarry, 2006). The basic idea behind this test can be illustrated with two simple equations:
(1) $\frac{A I S U}{A I S D}=\beta X+u$
(2) Usage $=\gamma X+\varepsilon$ 
Usage is the average usage of the line of credit, and $\mathrm{X}$ is a set of borrower characteristics observable to the bank at origination. If borrowers have private information about future credit line usage, borrowers with a high likelihood of usage will select into contracts with a lower AISU/AISD-ratio. We thus expect the residuals $\varepsilon$ and $u$ to be positively correlated (bad types have a high $\varepsilon$ and high $u$, good types have a low $\varepsilon$ and low $u$ ). The model can also be tested in a single-equation reduced form (see Finkelstein and Poterba (2004)):

$$
\text { (3) Usage }=\gamma X+\rho \frac{A I S U}{A I S D}+\varepsilon
$$

Equations (1) and (2) can be jointly estimated using seemingly unrelated regression (SUR) techniques. If control variables $\mathrm{X}$ are omitted, SUR reduces to a simple correlation between Usage and AISU/AISD. The reduced-form equation (3) can be estimated using standard OLS regression. We report multivariate results for equation (3) in Panel A of Appendix Table 5. In addition to the standard loan and borrower characteristics and fixed effects (see Appendix Table A) we also control for volatility and performance pricing to control for factors we have already identified as being relevant for the draw-down option in the hypothesis above. Consistent with our prior results, we find a positive and significant effect of the AISU/AISD-ratio on credit line usage rates.

\section{B.2. Utilization fee}

Description: Utilization fees are another tool to signal expected usage rates. Utilization fees increase the costs of draw-downs once draw-downs exceed a prespecified threshold (usually $33 \%$ or $50 \%$ ). Thus, borrowers that expect a low probability of large draw-downs can signal this by choosing a contract that specifies a utilization fee: 
Hypothesis 6: Borrowers who pay a utilization fee are less likely to draw on their line of credit.

Empirical evidence: Panel B of Table VII provides univariate tests for this hypothesis. Column (1) provides the fraction of loan contracts that contain a utilization fee. While only $6 \%$ of all loans in the lowest AISU/AISD-quintile include utilization fees, about $24 \%$ of all loans in the highest AISU/AISD quintile include utilization fees. These results suggest that the utilization fee is a partial substitute for a low AISU/AISD-ratio. Column (2) and (3) provide average usage ratios split by contracts that either contain or do not contain a utilization fee. We observe two main results: First, we find that average usage ratios are significantly lower for loans with utilization fees (see column (4)). In other words, borrowers that anticipate lower usage chose contracts that include a utilization fee consistent with Thakor and Udell (1987). Utilization fees are most common for medium quality borrowers (see Table II and the related discussion in Section I.C.). Given that usage rates increase significantly at the investment-grade/noninvestment-grade boundary, the need to signal future usage might be largest for medium quality borrowers. ${ }^{24}$ Second, the AISU/AISD-ratio is correlated with future usage only for contracts without utilization fees. Figure 3 shows this graphically by providing a histogram by AISU/AISD-ratio and existence of a utilization fee. We observe that credit lines with a high AISU/AISD-ratio are less likely to be left unused, while usage rates of $40 \%$ or higher are more likely for these credit lines. For contracts with a utilization fee, we observe no difference between high versus low AISU/AISD-ratios. Credit lines with a utilization fee are less likely to be heavily used.

\section{[Figure 3]}

\footnotetext{
${ }^{24}$ The fact that borrowers in the middle of the credit rating spectrum require more intense screening and monitoring is also consistent with Diamond (1991).
} 
Again, we test the relationship between future usage and the existence of a utilization fee more rigorously using the positive-correlation test. Results are reported in Panel B of Appendix Table 5. Consistent with the univariate results, we find that a higher utilization fee reduces usage rates and that the AISU/AISD-ratio is positively correlated with future usage only for contracts without utilization fee. ${ }^{25}$

\section{B.3. Screening or altering of ex-post incentives?}

The positive correlation test does not allow to distinguish between the hypotheses of fees being used as a screening device versus that of fees being used to alter borrowers' incentives expost (Finkelstein and Poterba (2004), Finkelstein and McGarry (2006)). To do so would either require either randomly assigning contracts ex-ante (to eliminate the screening explanation) or exogenously altering the pricing structure ex-post (to eliminate the ex-post incentives explanation). It is not our goal to find the natural experiment or perfect instrument. Rather, we seek to demonstrate that loan pricing structures are clearly correlated to ex-post usage of lines of credit. Future research might explore a setting as described above to distinguish between these explanations.

\section{Other options embedded in corporate loan contracts}

Until now, we have focused on the main options found in corporate loans - namely the option to draw down a line of credit and the "special cases" of the option to draw in the presence of a PP schedule or a competitive bid option. Loan contracts contain a variety of other options.

\footnotetext{
${ }^{25}$ Performance-pricing schemes are conceptually similar to a utilization fee because both vary the payment from the borrower to the lender based on some observable outcome that is correlated with the borrower's creditworthiness. Consistent with this argumentation, we find in unreported results that borrowers who have contracts with a performance pricing scheme are less likely to draw on their lines of credit.
} 
Due to lack of space, we cannot provide an exhaustive analysis for all options. However, we will briefly discuss other examples of options embedded in loan contracts.

First, term loans usually include the options to terminate a loan contract for a given charge (the cancellation fee). We discuss details about cancellation fees and the option to cancel a term loan contract in Online Appendix B. An analogy is the choice between mortgage points and interest rates in mortgage pricing that can be used to encourage self-selection based on the likelihood of early termination. ${ }^{26}$ Second, lines for letters of credits include the option to request a letter of credit. This option is similar to the option to draw under a line of credit, with the main exception that lenders provide a guarantee - but no liquidity - when a letter of credit is drawn. Third, some credit lines contain multicurrency options which give the borrower the right to choose the borrowing currency. Some features of syndicated loan contracts also provide options to lenders: Most contracts include material adverse change clauses (MAC) that give lenders the right to terminate a loan contract when a material adverse event is realized. ${ }^{27}$ Furthermore, covenants can be seen as an option for the lender to terminate or renegotiate a loan contract once a covenant is breached (Roberts and Sufi, 2009).

A fully comprehensive list of options embedded in corporate loan contracts is beyond the scope of this paper. Furthermore, we do not try to offer a complete explanation of the raison d'être or even a full assessment of the value of all these options. Rather, our aim is to point out to the types of options in corporate loan contracts and the role that fees play as a compensation and screening device for these options.

\footnotetext{
${ }^{26}$ Mortgage points are a form of upfront fee or original-issue discount (OID). By paying upfront fees at the beginning of a mortgage contract, borrowers can reduce the interest rate on the loan. Brueckner (1994) and LeRoy (1996) show that mortgage points can be used to screen borrowers on their likelihood of early termination.

${ }^{27}$ Material adverse events are usually only vaguely defined and thus allows the bank not to keep its illusory promise, see Boot, Greenbaum, and Thakor (1993) and Thakor (2005) for reputation-based models of MAC clauses.
} 


\section{Total Cost of Borrowing}

In the previous sections, we have shown that the pricing structure of loan commitments is complex and includes a variety of fees. We have tested theories as to why these fees exist and found that they are used to (1) price options embedded in loan contracts as well as (2) screen borrowers about the likelihood of exercising these option. We now propose a new total-cost-ofborrowing measure (TCB) that reflects all of these fees.

Once the menu of spread and fees has been negotiated, we can use this pricing structure to estimate the likelihood of exercising the embedded options and thus can calculate the TCB measure: ${ }^{28}$

$$
\begin{aligned}
& T C B=\text { Upfront Fee / Expected Loan Maturity in Years } \\
& +(1-P D D) \times(\text { Facility Fee }+ \text { Commitment Fee }) \\
& +P D D x(\text { Facility Fee }+ \text { Spread }) \\
& +P D D x \text { Prob(Utilization }>\text { UtilizationThreshhold } \mid \text { Usage >0) } x \text { Utilization Fee } \\
& + \text { Prob(Cancellation) } x \text { Cancellation Fee }
\end{aligned}
$$

where the expected loan maturity in years is measured as the difference between facility start and end date. $P D D$ is the likelihood that the credit line is drawn down; Prob(Utilization $>$ UtilizationThreshhold $\mid$ Usage $>0$ ) is the probability that the utilization of the credit line is higher than the thresholds specified in the loan contract conditional on observing utilization. Prob(Cancellation) is the probability that the loan is going to be canceled.

The TCB measure thus reflects the option characteristics of bank loans, differentiates between credit lines and term loans ( $P D D$ is 1 in case of term loans) and incorporates the various

\footnotetext{
${ }^{28}$ We provide an in-depth discussion as to how to calculate TCB in Online Appendix D using Dealscan data; we also provide the TCB measure and the program/code to compute the measure on our website.
} 
fees paid to lenders. The AISD, on the other hand, is defined as "Facility Fee + Spread" thereby ignoring important loan pricing components that we described above. We thus propose the TCB as an alternative to the AISD in future research exploring the cost of loans.

\section{Conclusion}

This study shows that fees are an important part of corporate loan contracts. We test the predictions of existing theories about the main purposes of fees and show that fees serve two main purposes: First, fees are compensation for options embedded in corporate loan contracts. Thus, high-creditworthiness-volatility borrowers need to pay higher upfront and unused fees to compensate lenders for providing a draw-down option. However, the draw-down option is worth less if the spread (partially) adjusts to the borrower's spot market spread, and thus performance sensitive loans have lower fees. Second, fees can be used to screen borrowers as to the likelihood of exercising any of these options. For example, we show that borrowers selecting into contracts with low unused fees (AISU) and high spreads are less likely to draw down their credit line than borrowers selecting into contracts with high unused fees and low spreads. Overall, our results suggest that analyzing the fees in the syndicated loan market can provide important insights into lender-borrower pricing behavior.

Looking forward, the results presented in this paper have important implications for the literature on loan contracting and loan pricing. First, researchers should be careful in pooling credit lines and term loans into a single syndicated loan sample. Option-like features differ widely between credit lines and term loans and thus, pricing and fee structures are different as well. Second, the analysis of a single measure, such as the AISD, is not sufficient to fully capture 
the richness of the pricing structure of corporate loans. However, once spreads and fees are set, we can use this pricing structure to estimate a total-cost-of-borrowing measure (TCB) that incorporates spreads and fees based on the likelihood that each of these components will have to be paid by the borrower.

Our hope is that this study inspires more research exploring the complexity of loan contracts. We have provided several suggestions throughout the paper that might be helpful in this regard. We also hope that the TCB, as a more comprehensive measure of the debt cost of capital (compared with the AISD), is useful to academics in future research. 


\section{References}

Adam, Tim, Valentin Burg, Tobias Scheinert, and Daniel Streitz, 2014, Managerial Optimism and Debt Contract Design, Working Paper.

Asquith, Paul, Anne Beatty, and Joseph Weber, 2005, Performance pricing in bank debt contracts, Journal of Accounting and Economics 40, 101-128.

Begley, Taylor A., 2013, Signaling, Financial Constraints, and Performance-Sensitive Debt, Working Paper.

Black, Fischer, and Myron Scholes, 1973, The pricing of options and corporate liabilities, Journal of Political Economy 81, 637-654.

Boot, Arnoud W.A., Stuart I. Greenbaum, and Anjan V. Thakor, 1993, Reputation and Discretion in Financial Contracting, American Economic Review 83, 1165-1183.

Boot, Arnoud W.A., Anjan V. Thakor, and Gregory F. Udell, 1987, Competition, Risk Neutrality and Loan Commitments, Journal of Banking and Finance 11,449-72.

Brueckner, Jan K., 1994, Borrower Mobility, Self-Selection, and Mortgage Points, Journal of Financial Intermediation 3, 416-441.

Chateau, John-Peter D., 1990, Valuation of Capped Variable Rate Loan Commitments, Journal of Banking and Finance 14, 717-728.

Chava, Sudheer, and Michael R. Roberts, 2008, How does financing impact investment? The role of debt covenants, The Journal of Finance 63, 2085-2121.

Diamond, Douglas W., 1991, Monitoring and Reputation: The Choice between Bank Loans and Directly Placed Debt, Journal of Political Economy 99, 689-721.

Ergungor, O. Emre, 2001, Theories of Bank Loan Commitments, Economic Review - Federal Reserve Bank of Cleveland 37, 2-19.

Finkelstein, Amy, and Kathleen McGarry, 2006, Multiple dimensions of private information: Evidence from the long-term care insurance market, American Economic Review 96, 938-958. 
Finkelstein, Amy, and James Poterba, 2004, Adverse selection in insurance markets: Policyholder evidence from the UK annuity market, Journal of Political Economy 112, 183-208. Ho, Thomas S.Y., and Anthony Saunders, 1983, Fixed-Rate Loan Commitments, Take-Down Risk, and the Dynamics of Hedging with Futures, Journal of Financial and Quantitative Analysis 18, 499-516.

Ivanov, Ivan, Joao A.C. Santos, and Thu Vo, 2014, The Transformation of Banking: Tying Loan Interest Rates to Borrower's CDS Spreads, Working Paper.

LeRoy, Stephen F., 1996, Mortgage Valuation Under Optimal Prepayment, Review of Financial Studies 9, 817-844.

Manso, Gustavo, Bruno Strulovici, and Alexei Tchistyi, 2010, Performance-sensitive debt, Review of Financial Studies 23, 1819-1854.

Roberts, Michael R., and Amir Sufi, 2009, Renegotiation of Financial Contracts: Evidence from Private Credit Agreements, Journal of Financial Economics 93, 159-184.

Shockley, Richard L. and Anjan V. Thakor, 1997, Bank Loan Commitment Contracts: Data, Theory, and Tests, Journal of Money, Credit and Banking 29, 517-534.

Sufi, Amir, 2009, Bank lines of credit in corporate finance: An empirical analysis, Review of Financial Studies 22, 1057-1088.

Taylor, Allison and Alicia Sansone, 2007, The Handbook of Loan Syndications and Trading, McGraw-Hill, New York, NY.

Thakor, Anjan V., Hai Hong, and Stuart I. Greenbaum, 1981, Bank loan commitments and interest rate volatility, Journal of Banking and Finance 5, 497-510.

Thakor, Anjan V., 1982, Toward a Theory of Bank Loan Commitments, Journal of Banking and Finance 6, 55-83.

Thakor, Anjan V., and Gregory F. Udell, 1987, An Economic Rationale for the Pricing Structure of Bank Loan Commitments, Journal of Banking and Finance 11, 271-289.

Thakor, Anjan V., 2005, Do Loan Commitments Cause Overlending?, Journal of Money, Credit, and Banking 37, 1067-1099. 
Figure 1

Spread and fee components of U.S. syndicated loans

This figure depicts fee types and the proportion of syndicated loans where the respective fee type is available in Dealscan. The column Percentage of contracts denotes the percentage of contracts where the respective fee is available in Dealscan. The column Mean (in bps) denotes the mean of the respective fee type in basis points as reported by Dealscan. Any fee is the percentage of syndicated loans where any fee is available on Dealscan. The sample is based on credit lines and term loans in the U.S. syndicated loan market from 1986 to 2011. Variables are defined in Appendix A.

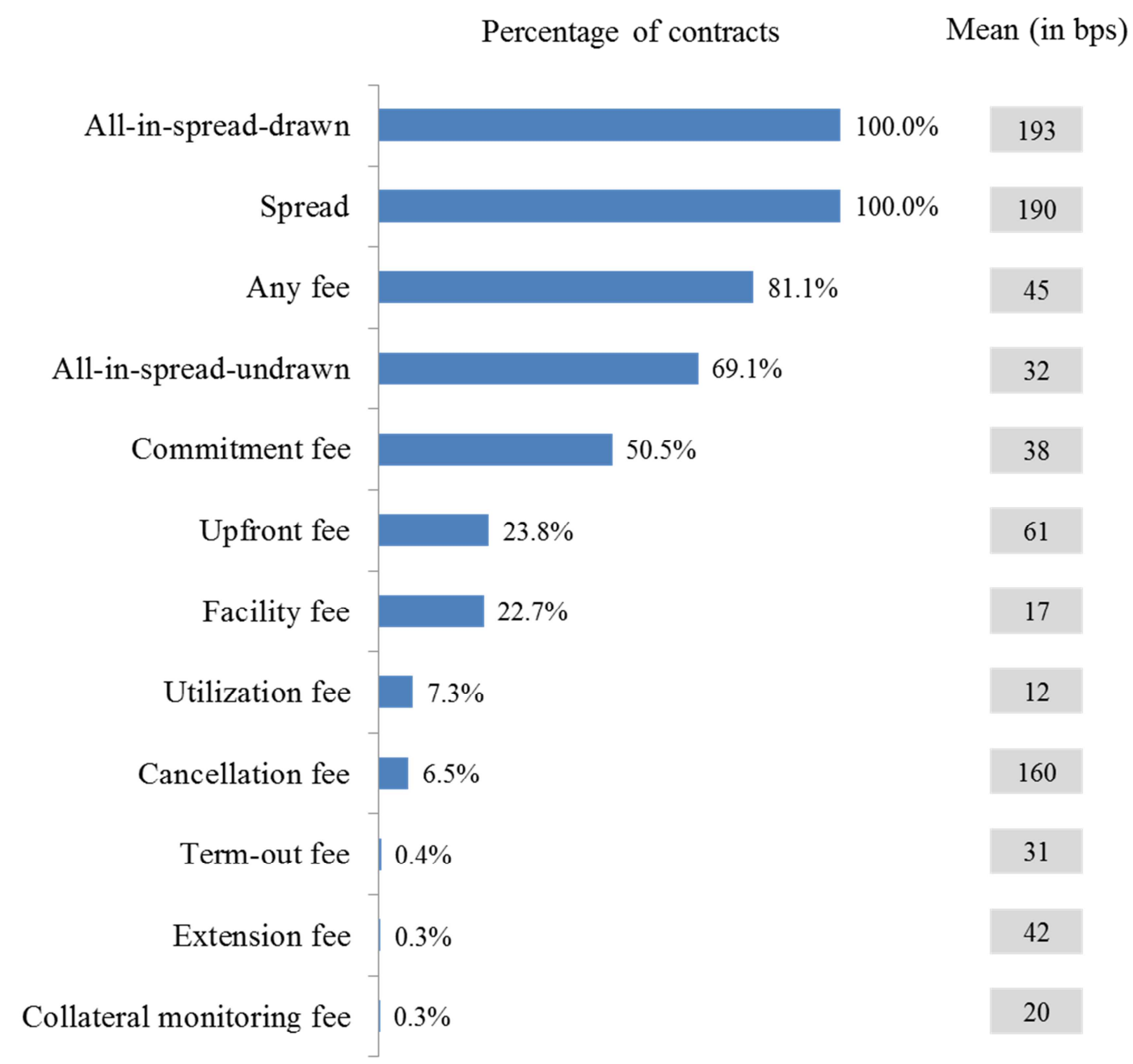




\section{Figure 2}

Spread and fee components of U.S. syndicated loans / Credit lines versus Term loans

This figure depicts fee types and the proportion of syndicated loans where the respective fee type is available in Dealscan. Panel A provides the results for term loans, Panel B provides the results for credit lines. The column Percentage of contracts denotes the percentage of contracts where the respective fee is available in Dealscan. The column Mean (in bps) denotes the unconditional mean of the respective fee type in basis points as reported by Dealscan. Any fee is the percentage of syndicated loans where any fee is available on Dealscan. The sample is based on credit lines and term loans in the U.S. syndicated loan market from 1986 to 2011. Variables are defined in Appendix A.
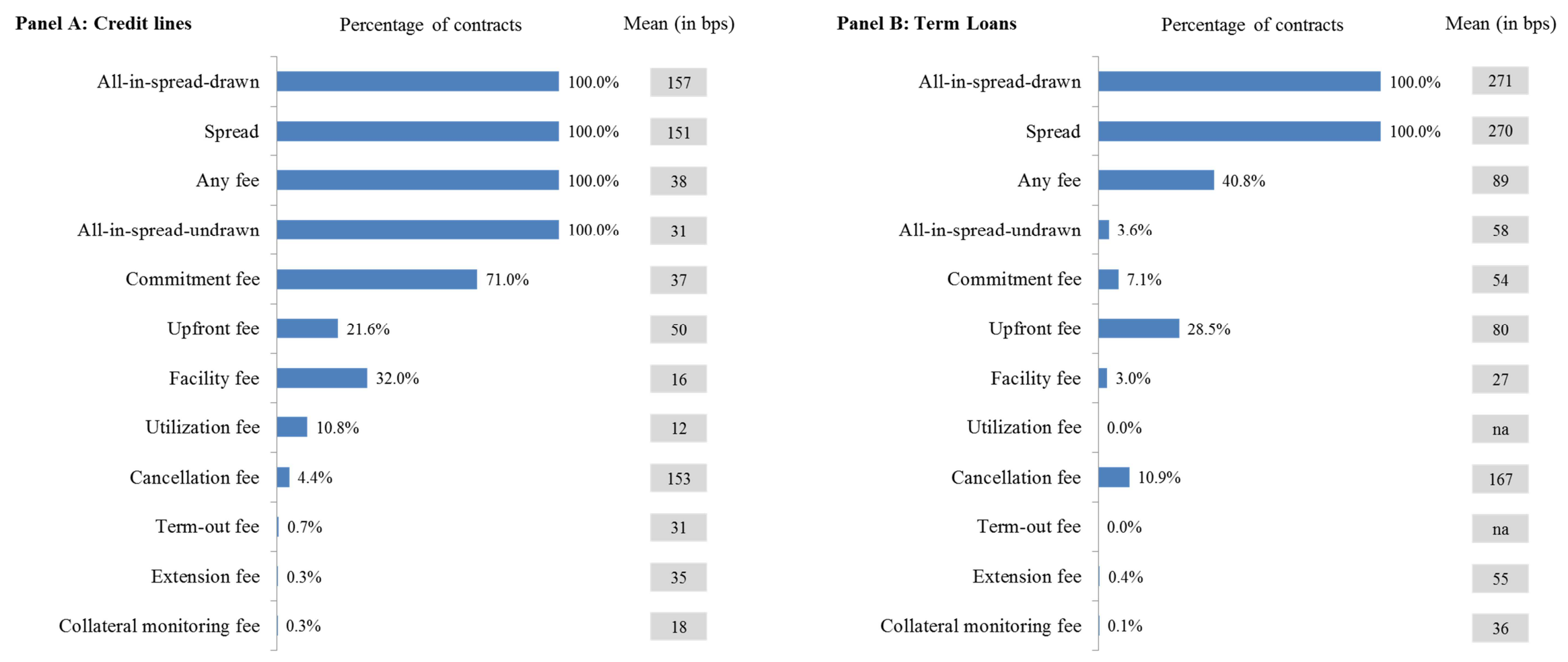
Figure 3

\section{Utilization of lines of credit}

This figure depicts histograms of the utilization of lines of credit over the first three years after origination. Panel A shows histograms for credit lines without a utilization fee, Panel B shows histograms for credit lines with a utilization fee. The green bars show histograms for credit lines in the lower two quintiles of the AISU/AISD-ratio, the solid bars show histograms for credit lines in the upper two quintiles of the AISU/AISD-ratio. The sample is based on credit lines in the U.S. syndicated loan market from 1986 to 2011 with available data on credit line usage from CapitalIQ. Variables are defined in Appendix A.

\section{Panel A: Contracts without utilization fee}

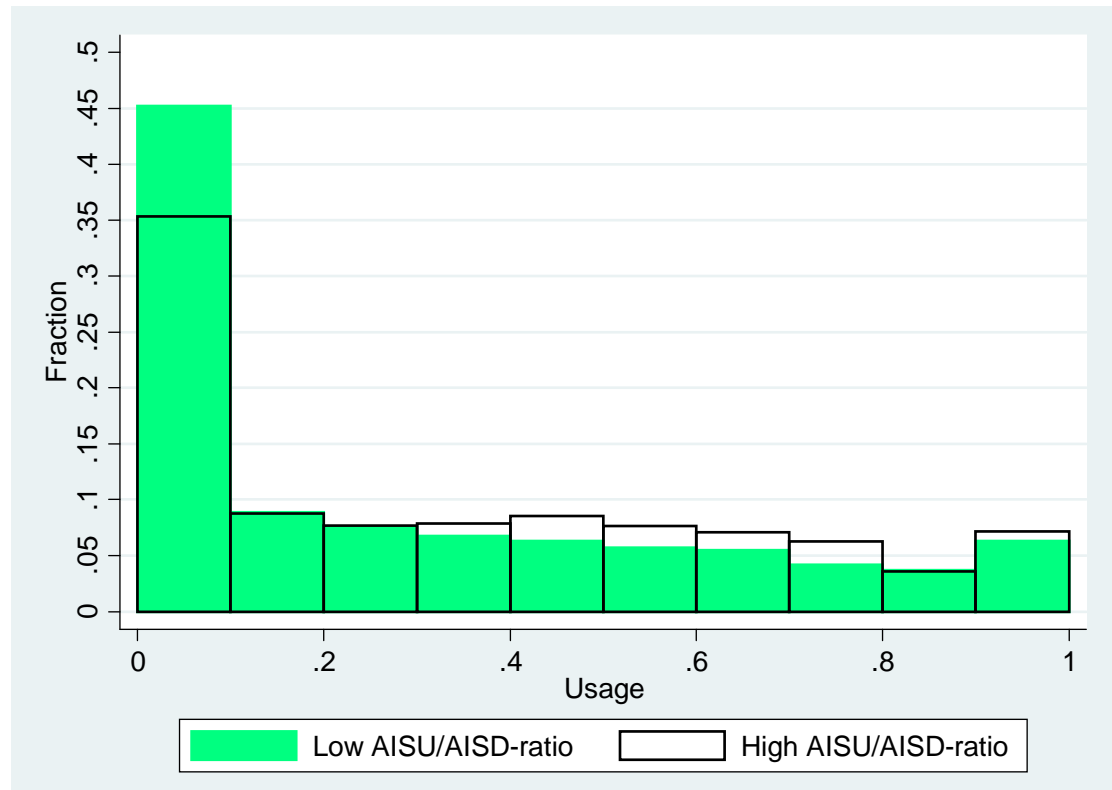

\section{Panel B: Contracts with utilization fee}

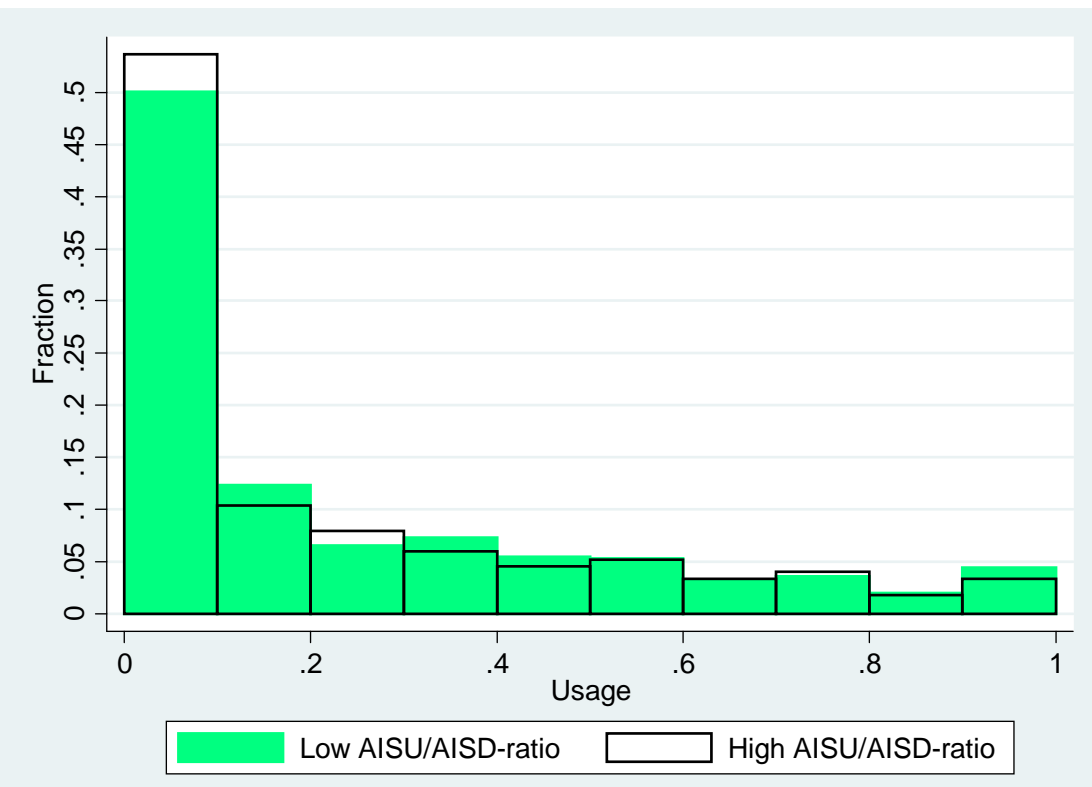


Table I: Comparing Credit Lines and Term Loans

This table provides summary statistics for key price terms, loan characteristics and borrower characteristics. Column "(I) Credit lines" reports summary statistics for the sample of credit lines, column "(II) Term loans" reports summary statistics for term loans. Panel A reports price terms, Panel B reports deal characteristics and Panel C reports borrower characteristics. The sample is based on credit lines and term loans in the U.S. syndicated loan market from 1986 to 2011. Variables are defined in Appendix A.

\begin{tabular}{|c|c|c|c|c|c|c|c|c|c|}
\hline \multirow[b]{2}{*}{ Variable } & \multirow[b]{2}{*}{ Unit } & \multicolumn{4}{|c|}{ (I) Credit Lines } & \multicolumn{4}{|c|}{ (II) Term Loans } \\
\hline & & $\mathbf{N}$ & Mean & Median & Std.Dev. & $\mathbf{N}$ & Mean & Median & Std.Dev. \\
\hline \multicolumn{10}{|l|}{ Panel A: Price terms } \\
\hline AISD & Basis points & 21,981 & 156.68 & 150.00 & 105.98 & 10,362 & 271.16 & 250.00 & 135.51 \\
\hline AISU & Basis points & 21,981 & 31.32 & 25.00 & 18.87 & 377 & 57.75 & 50.00 & 28.26 \\
\hline Spread & Basis points & 21,981 & 151.49 & 137.50 & 107.64 & 10,362 & 270.19 & 250.00 & 135.62 \\
\hline Commitment fee & Basis points & 15,620 & 37.02 & 37.50 & 17.75 & 735 & 54.34 & 50.00 & 29.90 \\
\hline Facility fee & Basis points & 7,025 & 16.16 & 12.50 & 12.49 & 313 & 27.22 & 25.00 & 19.70 \\
\hline Utilization fee & Basis points & 2,363 & 11.96 & 12.50 & 7.37 & 0 & NA & NA & NA \\
\hline Cancellation fee & Basis points & 971 & 153.46 & 100.00 & 101.27 & 1,127 & 166.51 & 100.00 & 101.46 \\
\hline Upfront fee & Basis points & 4,758 & 49.83 & 27.50 & 52.92 & 2,954 & 79.88 & 50.00 & 80.24 \\
\hline \multicolumn{10}{|c|}{ Panel B: Loan characteristics } \\
\hline Facility amount & USD mn & 21,981 & 350.72 & 151.86 & 527.80 & 10,362 & 248.05 & 108.74 & 416.77 \\
\hline Maturity & Months & 21,981 & 44.20 & 48.00 & 21.99 & 10,362 & 62.42 & 60.00 & 22.85 \\
\hline Secured & $0 / 1$ & 21,981 & 0.47 & 0.00 & 0.50 & 10,362 & 0.69 & 1.00 & 0.46 \\
\hline Sole lender $(0 / 1)$ & $0 / 1$ & 21,981 & 0.18 & 0.00 & 0.39 & 10,362 & 0.21 & 0.00 & 0.40 \\
\hline Syndicate size & Number & 21,981 & 8.53 & 6.00 & 8.17 & 10,362 & 7.44 & 4.50 & 8.35 \\
\hline Lead size & Number & 21,981 & 1.37 & 1.00 & 0.75 & 10,362 & 1.46 & 1.00 & 0.82 \\
\hline \multicolumn{10}{|c|}{ Panel C: Borrower characteristics } \\
\hline Total assets & USD mn & 20,659 & 4304.00 & 867.54 & 8943.08 & 8,923 & 2672.42 & 642.62 & 6336.97 \\
\hline Coverage & Percent & 19,693 & 17.70 & 5.67 & 46.41 & 8,516 & 14.16 & 3.80 & 44.26 \\
\hline Leverage & Number & 20,631 & 0.29 & 0.26 & 0.22 & 8,918 & 0.38 & 0.35 & 0.28 \\
\hline Profitability & Number & 20,474 & 0.17 & 0.13 & 0.13 & 8,822 & 0.16 & 0.13 & 0.13 \\
\hline Tangibility & Number & 20,585 & 0.35 & 0.30 & 0.24 & 8,887 & 0.33 & 0.28 & 0.23 \\
\hline Current ratio & Number & 19,691 & 1.86 & 1.57 & 1.19 & 8,581 & 1.86 & 1.55 & 1.27 \\
\hline Market-to-book & Number & 17,913 & 1.72 & 1.40 & 0.96 & 7,158 & 1.64 & 1.36 & 0.89 \\
\hline Investment grade & $0 / 1$ & 8,822 & 0.60 & 1.00 & 0.49 & 3,511 & 0.23 & 0.00 & 0.42 \\
\hline Not rated & $0 / 1$ & 21,981 & 0.60 & 1.00 & 0.49 & 10,362 & 0.66 & 1.00 & 0.47 \\
\hline
\end{tabular}




\section{Table II: Existence of fee types in syndicated loan contracts}

This table shows the existence of several fee types by S\&P rating class. The sample is based on credit lines and term loans in the U.S. syndicated loan market from 1986 to 2011. Variables are defined in Appendix A.

(1)

(2)

(3)

\begin{tabular}{|c|c|c|c|c|c|}
\hline & \multicolumn{3}{|c|}{ Credit lines } & \multirow{2}{*}{ Credit lines } & \multirow[t]{2}{*}{ Term Loans } \\
\hline & Facility & e versus Commi & ent fee & & \\
\hline Rating & $\begin{array}{c}\text { Facility Fee } \\
\text { only }\end{array}$ & $\begin{array}{l}\text { Commitment } \\
\text { Fee only }\end{array}$ & $\begin{array}{c}\text { Both } \\
\text { Fee Types }\end{array}$ & $\begin{array}{l}\text { Utilization } \\
\text { Fee }\end{array}$ & $\begin{array}{c}\text { Cancellation } \\
\text { Fee }\end{array}$ \\
\hline AAA/AA & $91.63 \%$ & $8.17 \%$ & $0.20 \%$ & $23.71 \%$ & $0.00 \%$ \\
\hline $\mathrm{A}+$ & $89.34 \%$ & $10.43 \%$ & $0.23 \%$ & $34.69 \%$ & $6.90 \%$ \\
\hline A & $87.25 \%$ & $11.74 \%$ & $1.01 \%$ & $42.06 \%$ & $3.16 \%$ \\
\hline A- & $80.63 \%$ & $17.72 \%$ & $1.65 \%$ & $40.99 \%$ & $11.11 \%$ \\
\hline $\mathrm{BBB}+$ & $72.63 \%$ & $25.85 \%$ & $1.52 \%$ & $45.50 \%$ & $2.96 \%$ \\
\hline BBB & $72.35 \%$ & $26.33 \%$ & $1.33 \%$ & $37.46 \%$ & $3.02 \%$ \\
\hline BBB- & $54.19 \%$ & $44.14 \%$ & $1.67 \%$ & $19.74 \%$ & $5.86 \%$ \\
\hline $\mathrm{BB}+$ & $28.00 \%$ & $70.86 \%$ & $1.14 \%$ & $9.14 \%$ & $7.84 \%$ \\
\hline $\mathrm{BB}$ & $12.23 \%$ & $86.04 \%$ & $1.73 \%$ & $3.17 \%$ & $10.33 \%$ \\
\hline BB- & $7.09 \%$ & $91.37 \%$ & $1.54 \%$ & $1.06 \%$ & $11.22 \%$ \\
\hline $\mathrm{B}+$ & $3.01 \%$ & $95.24 \%$ & $1.75 \%$ & $0.52 \%$ & $12.79 \%$ \\
\hline $\mathrm{B}$ & $4.95 \%$ & $93.49 \%$ & $1.56 \%$ & $0.53 \%$ & $23.16 \%$ \\
\hline B- and worse & $1.21 \%$ & $96.37 \%$ & $2.42 \%$ & $0.00 \%$ & $20.22 \%$ \\
\hline Unrated & $14.89 \%$ & $80.99 \%$ & $4.13 \%$ & $2.87 \%$ & $10.54 \%$ \\
\hline Total & $28.94 \%$ & $68.04 \%$ & $3.02 \%$ & $10.75 \%$ & $10.88 \%$ \\
\hline Total IG & $76.30 \%$ & $22.49 \%$ & $1.20 \%$ & $35.66 \%$ & $4.53 \%$ \\
\hline Total Non-IG & $9.67 \%$ & $88.70 \%$ & $1.63 \%$ & $2.46 \%$ & $13.58 \%$ \\
\hline
\end{tabular}




\section{Table III: Usage of credit lines and economic performance}

This table presents the usage of credit lines by economic performance. Usage is measured as the average percentage usage of the credit line in the first three years after origination. Economic performance is measured via the equity return over the first three years after loan origination (Panel A) and the change in profitability (EBITDA/sales) over the first three years after loan origination (Panel B). The sample is based on credit lines in the U.S. syndicated loan market from 1986 to 2011 for which information related to the usage is available in CapitalIQ. Variables are defined in Appendix A. ***,**,* denote significance at the 1,5 and $10 \%$ level, respectively.

Panel A: Measuring economic performance via equity returns

\begin{tabular}{lcccc}
\hline Quintile & IG & Non-IG & Not rated & Total \\
\hline 1 (Highest equity return) & $18.45 \%$ & $29.89 \%$ & $28.62 \%$ & $25.23 \%$ \\
2 & $20.18 \%$ & $28.57 \%$ & $29.65 \%$ & $25.98 \%$ \\
3 & $22.64 \%$ & $24.79 \%$ & $32.60 \%$ & $27.19 \%$ \\
4 & $19.97 \%$ & $28.35 \%$ & $34.53 \%$ & $27.83 \%$ \\
5 (Lowest equity return) & $20.20 \%$ & $36.04 \%$ & $43.20 \%$ & $33.23 \%$ \\
\hline \multirow{2}{*}{ Q5 - Q1 } & $1.75 \%$ & $6.15 \% * *$ & $14.58 \% * * *$ & $8.00 \% * * *$ \\
t-stat & $(1.07)$ & $(2.35)$ & $(7.71)$ & $(6.71)$ \\
\hline
\end{tabular}

Panel B: Measuring economic performance via changes in profitability (EBITDA/sales)

\begin{tabular}{lcccc}
\hline Quintile & IG & Non-IG & Not rated & Total \\
\hline 1 (Increasing profitability) & $21.56 \%$ & $32.46 \%$ & $33.74 \%$ & $29.63 \%$ \\
2 & $19.88 \%$ & $33.10 \%$ & $31.82 \%$ & $28.35 \%$ \\
3 & $18.58 \%$ & $28.76 \%$ & $32.87 \%$ & $27.48 \%$ \\
4 & $20.72 \%$ & $31.75 \%$ & $31.81 \%$ & $28.31 \%$ \\
5 (Decreasing profitability) & $24.27 \%$ & $36.87 \%$ & $39.93 \%$ & $34.33 \%$ \\
\hline \multirow{2}{*}{ Q5 - Q1 } & $2.71 \%$ & $4.41 \% *$ & $6.18 \% * * *$ & $4.70 \% * * *$ \\
t-stat & $(1.58)$ & $(1.88)$ & $(3.94)$ & $(4.39)$ \\
\hline
\end{tabular}




\section{Table IV: Upfront fees and AISU as a compensation for the option to draw}

This table presents the upfront fee and the All-in-spread-undrawn by quintile of the borrower's equity volatility. Panel A provides results for the upfront fee. Panel B provides results for the All-in-spread-undrawn. The sample is based on credit lines in the U.S. syndicated loan market from 1986 to 2011. Variables are defined in Appendix A. ***,**,* denote significance at the 1,5 and $10 \%$ level, respectively.

\section{Panel A: Upfront fee}

\begin{tabular}{lcccc}
\hline Quintile & IG & Non-IG & $\begin{array}{c}\text { Not } \\
\text { rated }\end{array}$ & Total \\
\hline 1 (Lowest volatility) & 25.01 & 38.33 & 30.10 & 30.64 \\
2 & 22.56 & 37.35 & 34.18 & 32.49 \\
3 & 27.66 & 54.09 & 40.76 & 40.68 \\
4 & 29.61 & 62.60 & 43.90 & 44.62 \\
5 (Highest volatility) & 44.30 & 79.87 & 58.31 & 59.62 \\
\hline Q5 - Q1 & $19.29 * * *$ & $41.54 * * *$ & $28.21 * * *$ & $28.98 * * *$ \\
t-stat & $(3.80)$ & $(5.81)$ & $(7.40)$ & $(9.91)$ \\
\hline
\end{tabular}

Panel B: All-in-spread-undrawn

\begin{tabular}{lcccc}
\hline Quintile & IG & Non-IG & $\begin{array}{c}\text { Not } \\
\text { rated }\end{array}$ & Total \\
\hline 1 (Lowest volatility) & 11.87 & 32.93 & 25.22 & 22.44 \\
2 & 12.43 & 37.06 & 30.26 & 25.92 \\
3 & 13.40 & 40.12 & 33.24 & 28.28 \\
4 & 14.72 & 43.29 & 35.60 & 30.46 \\
5 (Highest volatility) & 20.95 & 52.18 & 40.55 & 36.54 \\
\hline Q5 - Q1 & $9.08 * * *$ & $19.25 * * *$ & $15.33 * * *$ & $14.09 * * *$ \\
t-stat & $(13.17)$ & $(17.47)$ & $(24.86)$ & $(28.05)$ \\
\hline
\end{tabular}




\section{Table V: Performance pricing}

This table presents the upfront fee and the All-in-spread-undrawn by quintile of the borrower's equity volatility and by existence of a performance pricing scheme. . Panel A provides results for the upfront fee. Panel B provides results for the All-in-spread-undrawn. "PP - predominantly increasing (0/1)" is a dummy variable equal to one if the credit line contains a performance pricing scheme where the spread can increase more than it can decrease, "PP - predominantly decreasing (0/1)" is a dummy variable equal to one if the credit line contains a performance pricing scheme where the spread can decrease more than it can increase. The sample is based on credit lines in the U.S. syndicated loan market from 1986 to 2011. Variables are defined in Appendix A. ***, **, * denote significance at the 1,5 and $10 \%$ level, respectively.

Panel A: Performance pricing (PP) and the Upfront fee

\begin{tabular}{lccccc}
\hline & $\mathbf{( 1 )}$ & $\mathbf{( 2 )}$ & $\mathbf{( 3 )}$ & $\mathbf{( 4 )}$ & $\mathbf{( 5 )}$ \\
\hline Quintile & $\begin{array}{c}\mathbf{P P}- \\
\text { predominantly } \\
\text { decreasing }\end{array}$ & $\begin{array}{c}\text { No } \\
\text { performance } \\
\text { pricing }\end{array}$ & $\begin{array}{c}\text { PP - } \\
\text { predominantly } \\
\text { increasing }\end{array}$ & $\begin{array}{c}\text { Difference } \\
(\mathbf{1}) \text { versus (2) }\end{array}$ & $\begin{array}{c}\text { Difference } \\
\text { (3) versus (2) }\end{array}$ \\
\hline 1 (Lowest volatility) & 33.72 & 35.21 & 21.84 & $-1.48(-0.32)$ & $-13.37 * * *(3.42)$ \\
2 & 37.82 & 35.27 & 22.49 & $2.55(0.63)$ & $-12.78^{* * *}(3.50)$ \\
3 & 41.86 & 44.91 & 31.07 & $-3.05(-0.63)$ & $-13.84 * *(2.57)$ \\
4 & 47.62 & 48.75 & 33.51 & $-1.12(-0.25)$ & $-15.24 * * *(3.15)$ \\
5 (Highest volatility) & 57.43 & 67.02 & 47.81 & $-9.59 *(-1.67)$ & $-19.20^{* * *}(2.86)$ \\
\hline Q5 - Q1 & $23.71 * * *$ & $31.81 * * *$ & $25.97 * * *$ & & \\
t-stat & $(4.86)$ & $(6.07)$ & $(6.42)$ & & \\
\hline
\end{tabular}

Panel B: Performance pricing (PP) and the All-in-spread-undrawn

\begin{tabular}{lccccc}
\hline & $\mathbf{( 1 )}$ & $\mathbf{( 2 )}$ & $\mathbf{( 3 )}$ & $\mathbf{( 4 )}$ & $\mathbf{( 5 )}$ \\
\hline Quintile & $\begin{array}{c}\text { PP - } \\
\text { predominantly } \\
\text { decreasing }\end{array}$ & $\begin{array}{c}\text { No } \\
\text { performance } \\
\text { pricing }\end{array}$ & $\begin{array}{c}\text { PP - } \\
\text { predominantly } \\
\text { increasing }\end{array}$ & $\begin{array}{c}\text { Difference } \\
\text { (1) versus (2) }\end{array}$ & $\begin{array}{c}\text { Difference } \\
(\mathbf{3}) \text { versus (2) }\end{array}$ \\
\hline 1 (Lowest volatility) & 32.94 & 21.61 & 17.63 & $11.33^{* * *(14.56)}$ & $-3.98^{* * *}(-6.77)$ \\
2 & 35.88 & 25.28 & 19.81 & $10.60 * * *(13.44)$ & $-5.48^{* * *}(-8.13)$ \\
3 & 38.19 & 27.15 & 22.49 & $11.04 * * *(13.07)$ & $-4.66 * * *(-6.38)$ \\
4 & 40.56 & 28.33 & 24.36 & $12.23 * * *(14.76)$ & $-3.97 * * *(-5.01)$ \\
5 (Highest volatility) & 44.07 & 35.87 & 29.69 & $8.20 * * *(8.36)$ & $-6.18^{* * *}(-5.96)$ \\
\hline Q5 - Q1 & $11.13 * * *$ & $14.26 * * *$ & $12.06 * * *$ & & \\
t-stat & $(12.11)$ & $(17.78)$ & $(15.88)$ & & \\
\hline
\end{tabular}


Table VI: Facility fee versus commitment fee:

The role of creditworthiness and the competitive bid option

This table provides statistics on the existence of the facility and commitment fee for credit lines with and without competitive bid option. Panel A provides results for the facility fee. Panel B provides results for the commitment fee. The sample is based on credit lines in the U.S. syndicated loan market from 1986 to 2011. Variables are defined in Appendix A. ***,**,* denote significance at the 1, 5 and $10 \%$ level, respectively.

Panel A: Facility fee (0/1)

\begin{tabular}{lcccc}
\hline $\begin{array}{l}\text { Competitive Bid } \\
\text { Option }\end{array}$ & IG & Non-IG & Not rated & Total \\
\hline CBO in contract & $94.00 \%$ & $54.04 \%$ & $46.69 \%$ & $67.24 \%$ \\
CBO not in contract & $71.44 \%$ & $8.73 \%$ & $14.80 \%$ & $25.57 \%$ \\
\hline \multirow{2}{*}{ Difference } & $22.56 \% * * *$ & $45.31 \% * * *$ & $31.89 \% * * *$ & $41.67 \% * * *$ \\
t-stat & $(18.01)$ & $(20.72)$ & $(32.84)$ & $(50.41)$ \\
\hline
\end{tabular}

Panel B: Commitment fee (0/1)

\begin{tabular}{lcccc}
\hline $\begin{array}{l}\text { Competitive Bid } \\
\text { Option }\end{array}$ & IG & Non-IG & Not rated & Total \\
\hline CBO in contract & $8.93 \%$ & $48.99 \%$ & $64.63 \%$ & $40.03 \%$ \\
CBO not in contract & $29.13 \%$ & $92.81 \%$ & $88.23 \%$ & $76.68 \%$ \\
\hline Difference & $-20.20 \% * * *$ & $-43.82 \% * * *$ & $-23.60 \% * * *$ & $-36.65 \% * * *$ \\
t-stat & $(-15.72)$ & $(-21.57)$ & $(-26.42)$ & $(-45.13)$ \\
\hline
\end{tabular}




\section{Table VII: Usage as a function of the AISU/AISD ratio and the role of the utilization fee}

This table presents the usage by quintile of the credit line's AISU-to-AISD-ratio. The usage of credit lines is measured as the average credit line usage of the borrower over the first three years after origination based on data from CapitalIQ. Panel A provides results for the usage by quintile of the AISU-to-AISD-ratio and rating status (investment grade, non-investment grade, not rated, total). Panel B provides results for the usage existence of a utilization fee (column (1)) and the usage of the credit line by existence of utilization fee (column (2) and (3)). The sample is based on credit lines in the U.S. syndicated loan market from 1986 to 2011 with existing credit line usage data from CapitalIQ. Variables are defined in Appendix A. ***, **, * denote significance at the 1,5 and $10 \%$ level, respectively.

\section{Panel A: Usage and AISU/AISD-ratio}

\begin{tabular}{lcccc}
\hline $\begin{array}{l}\text { AISU/AISD- } \\
\text { ratio }\end{array}$ & IG & Non-IG & Not rated & Total \\
\hline 1 (Lowest ratio) & $17.95 \%$ & $30.17 \%$ & $34.88 \%$ & $28.74 \%$ \\
2 & $23.19 \%$ & $33.39 \%$ & $30.90 \%$ & $29.55 \%$ \\
3 & $20.81 \%$ & $30.77 \%$ & $33.42 \%$ & $29.11 \%$ \\
4 & $21.51 \%$ & $32.84 \%$ & $35.65 \%$ & $30.90 \%$ \\
5 (Highest ratio) & $22.21 \%$ & $34.98 \%$ & $40.08 \%$ & $32.38 \%$ \\
\hline Q5 - Q1 & $4.26 \% * *$ & $4.80 \% *$ & $5.21 \% * * *$ & $3.64 \% * * *$ \\
t-stat & $(2.38)$ & $(1.93)$ & $(2.95)$ & $(3.13)$ \\
\hline
\end{tabular}

Panel B: The role of the utilization fee

\begin{tabular}{lcccc}
\hline & $\mathbf{( 1 )}$ & $\mathbf{( 2 )}$ & $\mathbf{( 3 )}$ & $\mathbf{( 4 )}$ \\
\hline $\begin{array}{l}\text { AISU/AISD- } \\
\text { ratio }\end{array}$ & $\begin{array}{c}\text { Usage if } \\
\text { Utilization } \\
\text { fee (0/1) }\end{array}$ & $\begin{array}{c}\text { utization } \\
\text { fee does } \\
\text { not exists }\end{array}$ & $\begin{array}{c}\text { Usage if } \\
\text { utilization } \\
\text { fee exists }\end{array}$ & Difference \\
\hline 1 (Lowest ratio) & $5.69 \%$ & $28.87 \%$ & $26.66 \%$ & $2.20 \%$ \\
2 & $14.80 \%$ & $30.35 \%$ & $24.94 \%$ & $5.41 \% * * *$ \\
3 & $19.06 \%$ & $30.47 \%$ & $23.35 \%$ & $7.12 \% * * *$ \\
4 & $22.91 \%$ & $33.57 \%$ & $21.92 \%$ & $11.64 \% * * *$ \\
5 (Highest ratio) & $24.23 \%$ & $35.65 \%$ & $22.16 \%$ & $13.48 \% * * *$ \\
\hline Q5 - Q1 & $18.54 \% * * *$ & $6.78 \% * * *$ & $-4.50 \%$ & \\
t-stat & $(14.64)$ & $(5.28)$ & $(-1.36)$ & \\
\hline
\end{tabular}




\section{Appendix A \\ Explanation of variables}

\begin{tabular}{|c|c|c|}
\hline Variable & Source & Description \\
\hline \multicolumn{3}{|l|}{ General } \\
\hline Credit line & Dealscan & $\begin{array}{l}\text { Loans with type "Revolver/Line < } 1 \text { Yr.", "Revolver/Line >= } 1 \text { Yr.", } \\
\text { "364-Day Facility", "Limited Line" or "Revolver/Term Loan" as } \\
\text { indicated in the facility table in Dealscan }\end{array}$ \\
\hline Term Loan & Dealscan & $\begin{array}{l}\text { Loans with type "Term Loan", "Term Loan A"-“Term Loan H",or } \\
\text { "Delay Draw Term Loan" as indicated in the facility table in Dealscan }\end{array}$ \\
\hline Lead arranger & Dealscan & $\begin{array}{l}\text { We follow Bharath et al. (2011) and define a lender as a lead arranger if } \\
\text { at least one of the following conditions is met: 1) LeadArrangerCredit = } \\
\text { Yes in the LenderShares table of Dealscan, 2) LenderRole is equal to } \\
\text { "Agent", "Admin agent", "Arranger" or "Lead bank" in the } \\
\text { LenderShares table of Dealscan, 3) the lender is the sole lender. }\end{array}$ \\
\hline
\end{tabular}

\section{Price terms}

AISD

AISU

Spread

Commitment fee

Facility fee

Utilization fee

Cancellation fee

Upfront fee

\section{Loan characteristics}

Facility amount

Maturity

Secured (0/1)

Sole Lender (0/1)

Syndicate Size

Lead Size
Dealscan

Dealscan

Dealscan

Dealscan

Dealscan

Dealscan

Dealscan

Dealscan
All-In-Spread-Drawn, defined as the sum of the spread over LIBOR plus the facility fee

All-In-Spread-Undrawn, defined as the sum of the facility fee and the commitment fee

Spread over LIBOR (non-LIBOR-based loans are excluded from the sample) paid on drawn amounts on credit lines

Fee paid on the unused amount of loan commitments

Fee paid on the entire committed amount, regardless of usage

Fee paid on the entire drawn amount once a certain usage threshold has been exceeded

Fee paid if the syndicated loan is cancelled before maturity

Fee paid upon completion of a syndicated loan

Dealscan Facility amount in USD mn as indicated in the field FacilityAmt in the facility table in Dealscan, adjusted for inflation in year 2005 dollars Facility maturity in months as indicated in the field Maturity in the facility table in Dealscan

Dealscan

Dealscan

Dummy equal to 1 if a facility is secured as indicated by the field Secured in the facility table in Dealscan

Dealscan Dummy equal to 1 if a facility is provided solely by a single lender as indicated by the LenderShares table in Dealscan

Dealscan Number of lenders (lead arranger and participants) of a syndicated loan facility as indicated by the LenderShares table in Dealscan

Dealscan Number of lead arrangers of a syndicated loan facility as indicated by the LenderShares table in Dealscan 


\begin{tabular}{|c|c|c|}
\hline \multicolumn{3}{|c|}{ Borrower characteristics } \\
\hline Total assets & Compustat & Total assets in USD mn, adjusted for inflation in year 2005 dollars \\
\hline Coverage & Compustat & Ratio of EBITDA to interest expenses \\
\hline Leverage & Compustat & Ratio of book value of total debt to the book value of assets \\
\hline Profitability & Compustat & Ratio of EBITDA to sales \\
\hline Tangibility & Compustat & Ratio of property, plant and equipment to total assets \\
\hline Current ratio & Compustat & Ratio of current assets to current liabilities \\
\hline Market-to-book & Compustat & $\begin{array}{l}\text { Ratio of (book value of assets }- \text { book value of equity }+ \text { market value of } \\
\text { equity) to book value of assets }\end{array}$ \\
\hline Investment grade $(0 / 1)$ & Compustat & $\begin{array}{l}\text { Dummy equal to } 1 \text { if the } \mathrm{S} \& \mathrm{P} \text { rating is BBB- or higher. For non-rated } \\
\text { borrowers this dummy is missing }\end{array}$ \\
\hline Not rated $(0 / 1)$ & Compustat & Dummy equal to 1 if no S\&P rating for the borrower exists \\
\hline \multicolumn{3}{|l|}{ Other characteristics } \\
\hline Equity volatility & CRSP & $\begin{array}{l}\text { Equity volatility of the borrower's stock price, measured via daily stock } \\
\text { returns in the } 12 \text { months prior to loan origination }\end{array}$ \\
\hline Profitability volatility & Compustat & $\begin{array}{l}\text { Volatility of EBITDA/sales using annual report data over the three years } \\
\text { prior to loan origination }\end{array}$ \\
\hline $\operatorname{Spread}_{\min }\left(\operatorname{Spread}_{\max }\right)$ & Dealscan & $\begin{array}{l}\text { Minimum (Maximum) spread specified in the performance pricing } \\
\text { schedule. Equal to the spread if no performance pricing schedule exists }\end{array}$ \\
\hline $\begin{array}{l}\mathrm{PP} \text { - predominantly } \\
\text { increasing }(0 / 1)\end{array}$ & Dealscan & $\begin{array}{l}\text { Dummy equal to one if the credit line contains a performance pricing } \\
\text { scheme where the spread can increase more than it can decrease }\end{array}$ \\
\hline $\begin{array}{l}\mathrm{PP} \text { - predominantly } \\
\text { increasing }(0 / 1)\end{array}$ & Dealscan & $\begin{array}{l}\text { Dummy equal to one if the credit line contains a performance pricing } \\
\text { scheme where the spread can decrease more than it can decrease }\end{array}$ \\
\hline $\begin{array}{l}\text { PP (continuous } \\
\text { measure) }\end{array}$ & Dealscan & $\begin{array}{l}\left(\operatorname{Spread}_{\max }-\operatorname{Spread}_{\text {current }}\right)-\left(\operatorname{Spread}_{\text {current }}-\mathrm{Spread}_{\min }\right) \text {, where } \operatorname{Spread}_{\text {current }} \\
\text { denotes the spread specified in the loan contract as of loan origination }\end{array}$ \\
\hline
\end{tabular}




\section{Appendix B: Multivariate Results}

\section{Appendix Table 1: Usage of credit lines and economic performance (Multivariate results for Table III)}

This table provides results of a linear regression of the usage of credit lines on the economic performance and control variables. Usage is measured as the average usage of the credit line in the first three years after loan origination. Economic performance is measured via the equity return over the first three years after loan origination (Columns (1) and (2)) and the change in profitability (EBITDA/sales) over the first three years after loan origination (Column (3) and (4)). Column (1) and (3) provide results from a multivariate regressions with rating fixed effects (rating notch level). Column (2) and (4) provide results from a multivariate regressions controlling for loan and borrower characteristics as well as rating notch, year, loan purpose, loan type and one-digit SIC code fixed effects.. Variables are defined in Appendix A. We report tvalues based on standard errors clustered at the borrowing firm in parentheses. ***, **, * denote significance at the 1,5 and $10 \%$ level, respectively.

\begin{tabular}{|c|c|c|c|c|}
\hline & \multicolumn{2}{|c|}{$\begin{array}{c}\text { Panel A: } \\
\text { Measuring } \\
\text { economic performance } \\
\text { via equity returns }\end{array}$} & \multicolumn{2}{|c|}{$\begin{array}{c}\text { Panel B: } \\
\text { Measuring } \\
\text { economic performance } \\
\text { via changes in } \\
\text { profitability }\end{array}$} \\
\hline & (1) & (2) & (3) & (4) \\
\hline & $\begin{array}{l}\text { Credit } \\
\text { lines }\end{array}$ & Credit lines & Credit lines & Credit lines \\
\hline & Usage & Usage & Usage & Usage \\
\hline Equity Return & $\begin{array}{c}-0.062 * * * \\
(-6.78)\end{array}$ & $\begin{array}{c}-0.066 * * * \\
(-6.67)\end{array}$ & & \\
\hline Change in profitability (EBITDA/sales) & & & $\begin{array}{c}-0.205^{* * *} \\
(-3.39)\end{array}$ & $\begin{array}{c}-0.168 * * * \\
(-2.69)\end{array}$ \\
\hline Rating fixed effects & Yes & Yes & Yes & Yes \\
\hline Loan characteristics & No & Yes & No & Yes \\
\hline Borrower characteristics & No & Yes & No & Yes \\
\hline Year fixed effects & No & Yes & No & Yes \\
\hline Loan purpose fixed effects & No & Yes & No & Yes \\
\hline Loan type fixed effects & No & Yes & No & Yes \\
\hline One digit SIC code fixed effects & No & Yes & No & Yes \\
\hline Adj. $R^{2}$ & $6.95 \%$ & $19.38 \%$ & $5.09 \%$ & $18.34 \%$ \\
\hline Observations & 5,552 & 4,988 & 7,573 & 6,178 \\
\hline
\end{tabular}




\section{Appendix Table 2: Upfront fees and AISU as a compensation for the option to draw}

\section{(Multivariate results for Table IV)}

This table provides results of a linear regression of the upfront fee and the All-in-spread-undrawn on the measures of borrower riskiness and control variables. Panel I provides results using equity volatility (measured in percentage points) as a proxy for borrower riskiness and Panel II provides results using the standard deviation of profitability (measured as EBITDA/sales) over the three years preceding loan origination. Panel I.A/II.A provide results for the upfront fee, Panel I.B/II.B provide results for the All-in-spread-undrawn. Variables are defined in Appendix A. We report $\mathrm{t}$-values based on standard errors clustered at the borrowing firm in parentheses. ***, **, * denote significance at the 1,5 and $10 \%$ level, respectively.

\section{Panel I: Using equity volatility as a proxy for risk}

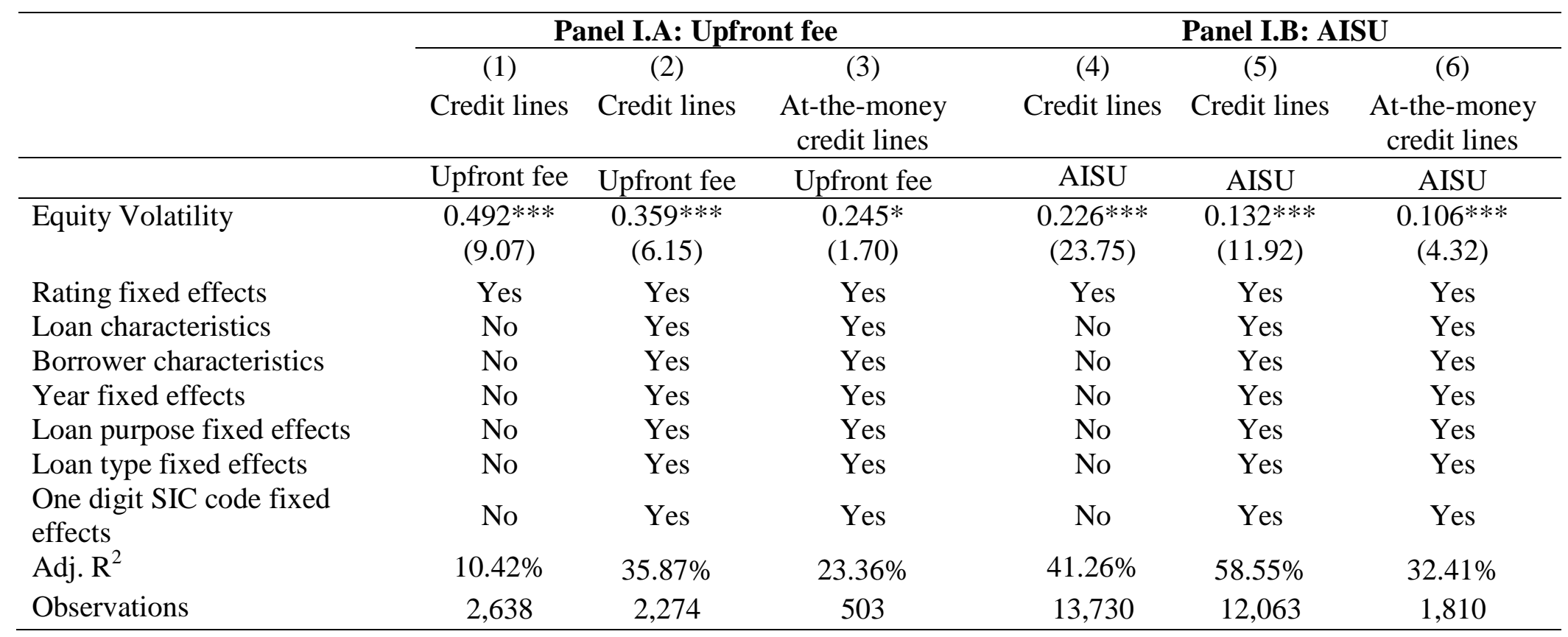


Panel II: Using volatility of profitability (EBITDA/sales) as a proxy for risk

\begin{tabular}{|c|c|c|c|c|c|c|}
\hline & \multicolumn{3}{|c|}{ Panel II.A: Upfront fee } & \multicolumn{3}{|c|}{ Panel II.B: AISU } \\
\hline & (1) & $(2)$ & $(3)$ & (4) & (5) & (6) \\
\hline & Credit lines & Credit lines & $\begin{array}{l}\text { At-the-money } \\
\text { credit lines }\end{array}$ & $\begin{array}{l}\text { Credit } \\
\text { lines }\end{array}$ & Credit lines & $\begin{array}{l}\text { At-the-money } \\
\text { credit lines }\end{array}$ \\
\hline & Upfront fee & Upfront fee & Upfront fee & AISU & AISU & AISU \\
\hline \multirow[t]{2}{*}{ Profitability volatility } & $58.293 * * *$ & $41.509 * * *$ & $69.454 *$ & $32.473 * * *$ & $14.497 * * *$ & $27.420 * * *$ \\
\hline & $(4.51)$ & $(2.67)$ & $(1.78)$ & $(10.76)$ & $(4.84)$ & $(3.63)$ \\
\hline Rating fixed effects & Yes & Yes & Yes & Yes & Yes & Yes \\
\hline Loan characteristics & No & Yes & Yes & No & Yes & Yes \\
\hline Borrower characteristics & No & Yes & Yes & No & Yes & Yes \\
\hline Year fixed effects & No & Yes & Yes & No & Yes & Yes \\
\hline Loan purpose fixed effects & No & Yes & Yes & No & Yes & Yes \\
\hline Loan type fixed effects & No & Yes & Yes & No & Yes & Yes \\
\hline $\begin{array}{l}\text { One digit SIC code fixed } \\
\text { effects }\end{array}$ & No & Yes & Yes & No & Yes & Yes \\
\hline Adj. $\mathrm{R}^{2}$ & $4.02 \%$ & $34.72 \%$ & $36.49 \%$ & $33.26 \%$ & $54.27 \%$ & $28.10 \%$ \\
\hline Observations & 3,739 & 3,141 & 734 & 18,277 & 15,659 & 2,488 \\
\hline
\end{tabular}




\section{Appendix Table 3: Performance pricing}

(Multivariate results for Table V)

This table provides results of a linear regression of the upfront fee and the All-in-spread-undrawn on performance pricing measures and control variables. Panel A provides results for the upfront fee, Panel B provides results for the AISU. "PP - predominantly increasing (0/1)" is a dummy variable equal to one if the credit line contains a performance pricing scheme where the spread can increase more than it can decrease, "PP - predominantly decreasing ( $0 / 1)$ " is a dummy variable equal to one if the credit line contains a performance pricing scheme where the spread can decrease more than it can increase. "PP (continuous measure)" is defined as $\left(\operatorname{Spread}_{\max }-\operatorname{Spread}_{\text {current }}\right)-\left(\operatorname{Spread}_{\text {current }}-\operatorname{Spread}_{\min }\right)$, where $\operatorname{Spread}_{\max }$ is the maximum spread from the performance pricing scheme, Spread $_{\min }$ is the minimum spread from the performance pricing scheme, and Spread $_{\text {current }}$ is the spread as of loan origination. Variables are defined in Appendix A. We report t-values based on standard errors clustered at the borrowing firm in parentheses. ***, **, * denote significance at the 1,5 and $10 \%$ level, respectively.

\begin{tabular}{|c|c|c|c|c|c|c|}
\hline & \multicolumn{3}{|c|}{ Panel A: Upfront fee } & \multicolumn{3}{|c|}{ Panel B: AISU } \\
\hline & (1) & (2) & (3) & (4) & (5) & $(6)$ \\
\hline & Credit lines & Credit lines & $\begin{array}{l}\text { Credit lines } \\
\text { if PP exists }\end{array}$ & Credit lines & Credit lines & $\begin{array}{l}\text { Credit lines } \\
\text { if PP exists }\end{array}$ \\
\hline & Upfront fee & Upfront fee & Upfront fee & AISU & AISU & AISU \\
\hline Equity Volatility & $\begin{array}{c}0.474 * * * \\
(8.77)\end{array}$ & $\begin{array}{c}0.352 * * * \\
(6.05)\end{array}$ & $\begin{array}{c}0.340 * * * \\
(4.49)\end{array}$ & $\begin{array}{c}0.215 * * * \\
(23.01)\end{array}$ & $\begin{array}{c}0.128 * * * \\
(11.72)\end{array}$ & $\begin{array}{c}0.096 * * * \\
(7.87)\end{array}$ \\
\hline $\mathrm{PP}$ - predominantly increasing $(0 / 1)$ & $\begin{array}{c}-13.086 * * * \\
(-6.03)\end{array}$ & $\begin{array}{c}-5.391 * * \\
(-2.38)\end{array}$ & & $\begin{array}{c}-4.216 * * * \\
(-12.71)\end{array}$ & $\begin{array}{c}-3.914 * * * \\
(-11.62)\end{array}$ & \\
\hline $\mathrm{PP}$ - predominantly decreasing $(0 / 1)$ & $\begin{array}{c}-5.029 * * \\
(-2.15)\end{array}$ & $\begin{array}{l}-2.726 \\
(-1.08)\end{array}$ & & $\begin{array}{c}5.267 * * * \\
(12.33)\end{array}$ & $\begin{array}{c}3.984 * * * \\
(8.96)\end{array}$ & \\
\hline PP (continuous measure) & & & $\begin{array}{c}-0.064 * * * \\
(-3.79)\end{array}$ & & & $\begin{array}{c}-0.086 * * * \\
(-22.70)\end{array}$ \\
\hline Rating fixed effects & Yes & Yes & Yes & Yes & Yes & Yes \\
\hline Loan characteristics & No & Yes & Yes & No & Yes & Yes \\
\hline Borrower characteristics & No & Yes & Yes & No & Yes & Yes \\
\hline Year fixed effects & No & Yes & Yes & No & Yes & Yes \\
\hline Loan purpose fixed effects & No & Yes & Yes & No & Yes & Yes \\
\hline Loan type fixed effects & No & Yes & Yes & No & Yes & Yes \\
\hline One digit SIC code fixed effects & No & Yes & Yes & No & Yes & Yes \\
\hline Adj. $R^{2}$ & $11.56 \%$ & $35.97 \%$ & $42.63 \%$ & $44.68 \%$ & $60.80 \%$ & $64.53 \%$ \\
\hline Observations & 2,638 & 2,274 & 1,319 & 13,730 & 12,063 & 6,846 \\
\hline
\end{tabular}




\section{Appendix Table 4: Facility fee versus commitment fee: The role of creditworthiness and the competitive bid option}

(Multivariate results for Table VI)

This table provides results of a regression of a facility fee dummy (Panel A) and commitment fee dummy (Panel B) on a competitive bid option dummy and control variables. The facility fee dummy (Panel A) is equal to 1 if the credit line contains a facility fee and zero otherwise. The commitment fee dummy (Panel B) is equal to 1 if the credit line contains a commitment fee and zero otherwise. Column (1) and (4) provides results of a linear regression with rating fixed effects (rating notch level), column (2) and (5) add loan characteristics, borrower characteristics, year, loan purpose, loan type, and one digit SIC code fixed effects, column (3) and (6) report average marginal effects from a logit regression. Variables are defined in Appendix A. We report t-values based on standard errors clustered at the borrowing firm in parentheses. ***, **, * denote significance at the 1,5 and $10 \%$ level, respectively.

\begin{tabular}{|c|c|c|c|c|c|c|}
\hline & \multicolumn{3}{|c|}{ Panel A: Facility fee } & \multicolumn{3}{|c|}{ Panel B: Commitment fee } \\
\hline & (1) & (2) & (3) & (4) & $(5)$ & (6) \\
\hline & Credit lines & Credit lines & Credit lines & Credit lines & Credit lines & Credit lines \\
\hline & $\begin{array}{c}\text { Facility fee } \\
(0 / 1)\end{array}$ & $\begin{array}{c}\text { Facility fee } \\
(0 / 1)\end{array}$ & $\begin{array}{c}\text { Facility fee } \\
(0 / 1)\end{array}$ & $\begin{array}{l}\text { Commitment } \\
\text { fee }(0 / 1)\end{array}$ & $\begin{array}{l}\text { Commitment } \\
\text { fee }(0 / 1)\end{array}$ & $\begin{array}{l}\text { Commitment } \\
\text { fee }(0 / 1)\end{array}$ \\
\hline & Linear & Linear & $\begin{array}{c}\text { Logit } \\
\text { (marg. effects) }\end{array}$ & Linear & Linear & $\begin{array}{c}\text { Logit } \\
\text { (marg. effects) }\end{array}$ \\
\hline $\mathrm{CBO}(0 / 1)$ & $\begin{array}{c}0.289 * * * \\
(25.80)\end{array}$ & $\begin{array}{c}0.250 * * * \\
(20.49)\end{array}$ & $\begin{array}{c}0.225 * * * \\
(16.21)\end{array}$ & $\begin{array}{c}-0.233 * * * \\
(-20.99)\end{array}$ & $\begin{array}{c}-0.212 * * * \\
(-17.81)\end{array}$ & $\begin{array}{c}-0.180 * * * \\
(-13.69)\end{array}$ \\
\hline Rating fixed effects & Yes & Yes & Yes & Yes & Yes & Yes \\
\hline Loan characteristics & No & Yes & Yes & No & Yes & Yes \\
\hline Borrower characteristics & No & Yes & Yes & No & Yes & Yes \\
\hline Year fixed effects & No & Yes & Yes & No & Yes & Yes \\
\hline Loan purpose fixed effects & No & Yes & Yes & No & Yes & Yes \\
\hline Loan type fixed effects & No & Yes & Yes & No & Yes & Yes \\
\hline One digit SIC code fixed effects & No & Yes & Yes & No & Yes & Yes \\
\hline Adj. $R^{2}$, Pseudo $R^{2}$ & $37.53 \%$ & $46.35 \%$ & $41.42 \%$ & $40.50 \%$ & $50.00 \%$ & $45.91 \%$ \\
\hline Observations & 21,981 & 16,329 & 16,329 & 21,981 & 16,329 & 16,329 \\
\hline
\end{tabular}




\section{Appendix Table 5: Usage as a function of the AISU/AISD-ratio and the role of the utilization fee}

(Multivariate results for Table VII)

This table provides results of a regression of the mean credit line usage over the first three years after loan origination on the AISU/AISDratio, the utilization fee, and control variables. Panel A provides results for the AISU/AISD-ratio. Panel B provides results for the utilization fee and combinations of the utilization fee and the AISU/AISD-ratio. Column (1) and (3) report results for a regression with rating fixed effects (rating notch level), column (2), (4) and (5) add loan characteristics, borrower characteristics, year, loan purpose, loan type, and one digit SIC code fixed effects. Variables are defined in Appendix A. We report t-values based on standard errors clustered at the borrowing firm in parentheses. $* * * * *, *$ denote significance at the 1,5 and $10 \%$ level, respectively.

\begin{tabular}{|c|c|c|c|c|c|}
\hline & Panel A: Usage & AISU/AISD-ratio & Panel B: T & role of the & ilization fee \\
\hline & $(1)$ & $(2)$ & $(3)$ & $(4)$ & $(5)$ \\
\hline & Credit lines & Credit lines & Credit lines & Credit lines & Credit lines \\
\hline & Usage & Usage & Usage & Usage & Usage \\
\hline AISU/AISD-ratio & $\begin{array}{c}0.307 * * * \\
(5.09)\end{array}$ & $\begin{array}{l}0.128 * \\
(1.68)\end{array}$ & & & \\
\hline $\mathrm{UTF}==0 \times$ AISU/AISD-ratio & & & & & $\begin{array}{c}0.144 * \\
(1.83)\end{array}$ \\
\hline $\mathrm{UTF}==1 \times$ AISU/AISD-ratio & & & & & $\begin{array}{l}0.033 \\
(0.18)\end{array}$ \\
\hline $\operatorname{UTF}(0 / 1)$ & & & $\begin{array}{c}0.028 * \\
(1.70)\end{array}$ & $\begin{array}{l}0.027 \\
(1.45)\end{array}$ & $\begin{array}{l}0.050 \\
(1.12)\end{array}$ \\
\hline UTF & & & $\begin{array}{c}-0.002 * * * \\
(-3.15)\end{array}$ & $\begin{array}{c}-0.002 * * * \\
(-2.77)\end{array}$ & $\begin{array}{c}-0.002 * * * \\
(-2.79)\end{array}$ \\
\hline Rating fixed effects & Yes & Yes & Yes & Yes & Yes \\
\hline Loan characteristics & No & Yes & No & Yes & Yes \\
\hline Borrower characteristics & No & Yes & No & Yes & Yes \\
\hline Year fixed effects & No & Yes & No & Yes & Yes \\
\hline Loan purpose fixed effects & No & Yes & No & Yes & Yes \\
\hline Loan type fixed effects & No & Yes & No & Yes & Yes \\
\hline One digit SIC code fixed effects & No & Yes & No & Yes & Yes \\
\hline Controls for volatility and performance pricing & No & Yes & No & Yes & Yes \\
\hline Adj. $R^{2}$ & $5.34 \%$ & $17.58 \%$ & $4.88 \%$ & $17.61 \%$ & $17.67 \%$ \\
\hline Observations & 7,843 & 6,099 & 7,843 & 6,099 & 6,099 \\
\hline
\end{tabular}

